\title{
Anx7 Is Required for Nutritional Control of Gene Expression in Mouse Pancreatic Islets of Langerhans
}

\author{
Meera Srivastava, Ofer Eidelman, Ximena Leighton, Mirta Glasman, Gertrude Goping, \\ and Harvey B. Pollard \\ Department of Anatomy, Physiology and Genetics and Institute for Molecular Medicine, USU School \\ of Medicine, Bethesda, MD, USA \\ Accepted October 3, 2002
}

\begin{abstract}
Background: Gene expression in islets of Langerhans is profoundly sensitive to glucose and other nutrients. Islets of Langerhans in the Anx7(+/-) knockout mouse exhibit a profound reduction in ITPR3 protein expression, defective intracellular calcium signaling, and defective insulin secretion. Additional data presented here also show that mRNA for ITPR3 is virtually undetectable in isolated Anx7(+/-) islets. IP3Receptor type 3 (ITPR3) expression in islets of Langerhans is closely regulated by secretory stimuli, and it has been suggested that the level of the ITPR3 expression controls the ability of the islets to respond to nutritional signals. We report that although control islets respond to glucose in vitro by a transient increment in ITPR3 mRNA, the islets from the Anx7(+/-) mouse remain low. We therefore hypothesized that the Anx7/IP3 Receptor(3)/ $\mathrm{Ca}^{2+}$ signaling pathway plays a role in $\beta$ cell responses to glucose, and that in the absence of the Anx7/ITPR3 signaling system, the islets would be unable to discriminate between fed or fasted states in vivo.

Materials and Methods: To test this hypothesis, we subjected Anx7(+/-) and control mice to either food and water ad libidum or to an overnight fast with access to water only. We then isolated the respective islets and compared nutrient-dependent changes in global gene expression under the four conditions using genome-based microarray technology. Results: Anx7 protein expression in these islets is only about $50 \%$ of control levels in normal littermate controls, and IPTR 3 message and protein are virtually zero. cDNA
\end{abstract}

microarray analyses show that in control animals gene expression is significantly affected by the fasting state. Many of the affected genes have historical relevance to development and differentiation of islets. These include preproglucagon, APOJ, cadherin2, phosphoglucoisomerase, oncostatin M, PAX6, HGF, and cytokeratin 18. However, there are also many other nutritionally sensitive genes in control islets that are principally associated with cell division and DNA repair. The latter genes have not specifically been associated with islet physiology in the past. By contrast, Anx7(+/-) mouse islets exhibit a greatly reduced ability to discriminate genomically between fed and fasted states for all classes of identified genes. Many of the validated genes are specific to islets in comparison to liver tissue examined. Real-time quantitative RT-PCR analysis of islets from $A n x 7$ heterozygous mice and littermate controls revealed remarkable down-regulation in PTEN, Glut2, PDX-1, IGF-1, and Neuro D 1 expression, but not in liver. Conclusions: We conclude that reduced gene dosage in the Anx7(+I-) islet, with concomitant loss of ITPR3 expression and consequent defects in $\mathrm{Ca}^{2+}$ signaling, may substantially contribute to the mechanism of the loss of genomic discrimination, in vivo, between the fed and fasted states. We believe that the requirement for complete Anx7 gene dosage and IPTR3 expression in islets of Langerhans will prove to be of fundamental importance for understanding the mechanism of nutritional sensing in health and disease.

\section{Introduction}

Beta and other endocrine cells in pancreatic islets of Langerhans function to regulate glucose homeostasis in response to dynamic changes in the nutritional

M. S. and O. E. contributed equally to this manuscript. Address correspondence and reprint requests to: Meera Srivastava, Department of Anatomy, Physiology and Genetics, USU School of Medicine (USUHS), 4301 Jones Bridge Road, Bethesda, MD, 20814 USA. Phone: 301-295-3204;

fax: 301-295-2822; e-mails: msrivastava@usuhs.mil state of the organism (1). At the level of the whole organism, such conclusions have been validated on the basis of decades of classical physiology and biochemistry (2-4). However, in most cases the detailed mechanisms underlying these conclusions have been investigated primarily using in vitro experiments with isolated islets or purified $\beta$ cell cultures (5-7). An underlying and still unrequited concern has therefore been the question of whether what was true of islets after hr or days in culture truly reflected the state of 
the same tissue in vivo. From the vantage point of understanding nutritional effects on islet gene expression, an additional problem has been the fact that conventional studies have mostly been conducted in terms of one or two genes at a time. Therefore, attempts to synthesize a global perspective from many such discrete experiments has proved difficult. In addition, transgenic or gene knockout experiments have been used to determine the developmental signaling steps in islet development $(8,9)$. However, there are few if any reports of nutritional studies using such mutant islets or of $\beta$ cells derived from such islets.

More recently, new genome-based microarray technologies have been developed that permit the identification of global systems of genes that underlie physiologic or disease-related processes such as nutrition (10). This new technology has been specifically applied to nutritional problems in intact animals using large organs such as liver and kidney, or large cell cultures as the source of mRNA $(11,12)$. As an alternative to fluorescence labeling methods, which require large amounts of RNA, we and others have used the more sensitive radiolabeled cDNA transcripts of endogenous mRNA's as probes for cDNA microarray analysis of gene expression $(13,14)$. Using the radiolabel approach, we have been able to test the hypothesis that there exist sets of islet-specific genes whose expression is regulated by the nutritional status of the organism.

At the level of islet physiology in vitro, $\mathrm{Ca}^{2+}$ is very important for islet function, both as a secretagogic intermediate $(15,16)$, and, potentially, as a mediator of genomic responses to nutritional challenges. For example, isolated islets have been shown to respond to glucose in minutes by a rapid, de novo synthesis of mRNA for the inositol 1,4,5 triphosphate receptor, type 3 (ITPR3). This nuclear event is followed promptly by cytoplasmic synthesis of the cognate protein, insertion into the endoplasmic reticulum, and quick proteosomic destruction $(17,18)$. Thus, it has been proposed that the regulation of ITPR3 synthesis, function, and metabolism is intimately linked to $\mathrm{Ca}^{2+}$ signaling and insulin secretion in vivo (19). Of course, whether such data from isolated islets are valid for the in vivo condition is not known. In addition, one might anticipate that from a global perspective, there may be many more genes such as ITPR3, with possibly as much or greater importance for control of nutritional genomics. We have hypothesized that the Anx7 gene might be one such example, and the possibility of testing this hypothesis exists because the Anx7(+I-) knockout mouse is available to provide islets for analysis (20). Relevantly, the giant islets from these mutant mice fail to express the ITPR3 gene or protein, and exhibit $\mathrm{Ca}^{2+}$ signaling defects and low rates of $\mathrm{Ca}^{2+}$-dependent insulin secretion in response to glucose (20). The $\beta$ cell content of control and Anx7(+/-) islets are $76 \%$ and $80 \%$, respectively (21), suggesting that the genomic data principally reflect nuclear events in $\beta$ cells.
To initiate a study of nutritional genomics for islets of Langerhans, we have examined the global expression of islets from mice killed at $9 \mathrm{AM}$, after having been either fasted for $16 \mathrm{hr}$ overnight or allowed food ad libidum during the same time period. The choice of timing is critical because there are many genes whose expression is circadian (12). We have also examined the islets from Anx7(+/-) knockout mice under the same nutritional conditions. In designing these experiments, we presumed that the nutritional genomics of islets in the fed and fasted states would reveal important information regarding how the cells in islets dealt with an evolutionarily relevant type of stress. We further presumed that should the deficit in ANX7 gene dosage and subsequent loss of ITPR 3 be as important as anticipated, then it was possible that that islets from the knockout animals might fail to discriminate globally between fed and fasted conditions.

In this paper we report that gene expression in islets prepared from fed or overnight-fasted normal mice does vary quite profoundly. We find that genes principally associated with growth and differentiation of $\beta$ cells are principally up-regulated under fasting conditions. By contrast, islets from Anx7(+/-) knockout mice fail to significantly discriminate between the two nutritional states. This is the first such study to analyze nutritional genomics of islets of Langerhans at the organismic level. We suggest that identification of the sets of nutritionally regulated genes in islets and their abrogation by the Anx7(+/-) mutation may therefore yield important insights into the control of homeostatic mechanisms, as well as increase understanding of disease states affecting islets, including diabetes.

\section{Materials and Methods}

Derivation and Husbandry of Anx7(+/-) Knockout Mice

The $A n x 7(+/-)$ mice were generated as described by Srivastava et al. (20). Briefly, genomic anx7 DNA clones, isolated from an isogenic strain of mice $(129 / \mathrm{sv})$, were used to construct a gene targeting vector in which anx7 sequences encompassing exon 6 were replaced with the neo gene. This vector was designed to remove the coding sequences responsible for binding calcium and GTP. Heterozygous mice thereby generated were identified by polymerase chain reaction (PCR) analysis of genomic DNA isolated from tail samples of the offspring. The Anx7(-/-) homozygote is lethal, not surviving beyond E10. In these experiments, data are restricted to male mice in the age range of 180-210 days old. Control mice were normal littermate controls.

\section{Experimental Design and Isolation of Islets of Langerhans}

Anx7(+/-) and normal littermate control mice were allowed food and water ad libidum until initiation of islet isolation. In some cases these animals were denied food for $16 \mathrm{hr}$ (overnight, 5 PM to $9 \mathrm{AM}$ ). When 
provided with food, mutant and normal littermate controls consumed qualitatively equivalent amounts of food and water over the course of the 16-hr experiment. Immediately prior to sacrifice, blood was obtained by tail vein from each mouse for measurement of blood glucose and insulin levels. Baseline values were obtained for each mouse 1 week prior to the initiation of the experiment. Islet isolation was initiated systematically at $9 \mathrm{AM}$. Pancreatic islets from An $x 7(+/+)$ and $\operatorname{an} \times 7(+/-)$ mice were isolated by collagenase digestion as previously described (22). Data were collected using eight animal pairs.

\section{Glucose and Insulin Contents in Mouse Serum}

One hundred-thirty Anx7(+/-) and anx7(+/+) mice over 100 days old were fasted overnight and blood collected the next morning for measurement of fasting blood sugar and insulin. Blood sugar was measured with a calibrated glucometer and insulin was measured by a radioimmunoassay using ${ }^{125}[\mathrm{I}]$ bovine insulin and a guinea pig anti-porcine insulin antibody for detection.

\section{Glucose Tolerance and Insulin Tolerance Tests} for Anx7(+1-) Knockout Mice

We performed glucose tolerance tests (GTT) by IP injection of a bolus of $2 \mathrm{mg}$ glucose/g body weight and insulin tolerance tests (ITT) by IP injection of $1.0 \mathrm{U}$ regular insulin/kg body weight. Glucose and insulin were as described above.

\section{Measurement of Hormone Levels in Mouse Serum}

Seven littermate pairs of male and female animals were used for these analyses. We collected samples of serum from animals fasted overnight and examined the blood levels of growth hormone, insulin-like growth factor-1 (IGF-1), estrogen, testosterone, corticosterone, fatty acids, and triglycerides. IGF-1 measurements were obtained by a double antibody radioimmunoassay using recombinant human IGF- 1 and anti-human IGF-1 serum UBK487 (Endocrine Sciences, San Diego, CA, USA) after removal of binding proteins from a $5-\mu \mathrm{l}$ aliquot of serum using Sep-Pak C18 reverse phase cartridge (Millipore). Corticosterone was measured using ${ }^{125} \mathrm{I}$-corticosterone and anti-corticosterone antibody. Glucagon and testosterone were measured by radioimmunoassays using ${ }^{125} \mathrm{I}$-glucagon and anti-glucagon antibody and ${ }^{125} \mathrm{I}$ testosterone anti-testosterone antibody, respectively. Growth hormone is species specific; therefore, radioimmunoassay was performed by utilizing speciesspecific (NIDDK) reagents obtained from the Pituitary Hormones and Antisera Center.

Measurement of Islet ITPR Types 1, 2, and 3 mRNA by RT-PCR

We measured ANX7 and IP3-receptor mRNA levels in Anx7(+/-) and Anx7(+/+) islets. Quantitative
RT-PCR was used to quantitate the IP3Receptor messages (types 1,2 , and 3). Levels of $\beta$-actin message were used to normalize levels of RNA used for the analyses. IP3 receptors come in three subtypes, in which only a discrete domain varies among the three. The following mouse primers were prepared and tested in these experiments.

Type 1 = forward primer: 5'-CACCGCGGCAGAGATTGACAC-3' reverse primer: 5'-CCAGCTGCCCGGAGATTTC-3'

Type 2 = forward primer: 5'-CTGGGGCCAACGCTAATACTACTT-3' reverse primer: 5'-GAACCCCGTGATTACCTGTGACTG-3'

Type 3 = forward primer: 5'-GCGGGCCTGTGACACTCTACTTAT-3'reverse primer: 5'-CGCCGCTCACCAGGGACAT-3'

\section{cDNA Microarray Analysis of mRNAs From Mouse Islets}

Total RNA was prepared from islets, and cDNA copies were labeled with $\left[{ }^{32} \mathrm{P}\right]$ as described by Srivastava et al. (20). Mouse cDNA microarrays on nylon membranes were obtained from Clontech, and were prehybridized using Express Hyb (Clontech, Palo Alto, CA, USA) at $68^{\circ} \mathrm{C}$ for $1 \mathrm{hr}$, and then incubated overnight in Express Hyb with the denatured and neutralized labeled probes. Following this incubation, the membranes were washed three times and exposed for $6 \mathrm{hr}$ on a Storm Phosphorlmager plate (Molecular Dynamics, Sunnyvale, CA, USA). Data were collected in duplicate.

\section{Imaging and Quantitation of $c D N A$ Microarrays}

Imaging data from the Storm PhosphorImager were downloaded into a Microsoft Excel spreadsheet. Duplicate data points were ratioed either to the ubiquitin standard or to the average expression of the entire array. Data were then analyzed using the Stanford University ScanAlyze software. These data were also evaluated in parallel with the PSCAN program for point identification and with the JMP program for graphical organization.

\section{Statistical Data Mining From cDNA Arrays by GRASP and HELP Algorithms}

The initial strategy we employed is embodied in the GRASP algorithm (Gene Ratio AnalysiS Paradigm, $13,14)$. The GRASP algorithm allows us to specify the changes in specific intensities of given genes which are greater or less than one or more standard deviation (SD) from the average changes of all genes in the entire array. The second strategy we employed was to examine the differential effect of the fed versus the fasted states of control and mutant islets using HELP (Heliometric Plot) diagrams. In this diagram, the horizontal axis is gene expression in mutant islets under fed conditions and the vertical axis is gene expression in mutant islets under fasted conditions. On the vertical axis at the point $0,0 \mathrm{we}$ inscribe the fed/fasted ratio of gene expression of control islets. An arrow is then drawn from the 
control ratio point on the central vertical axis to the point describing the expression under both conditions in mutant islets. When the arrow terminates on the diagonal, expression is equal in mutant islets in both fed and fasted states. The length of the arrow is the magnitude of change of gene expression as one transitions from control to mutant mice. The value of this HELP diagram is that it helps reveal, at a glance, the relative expression of genes in the fed versus fasted state in both control and mutant mouse islets.

Validation of Candidate Gene Expression in Islets and Liver From Mutant and Control Mice Using Real-Time Quantitative RT-PCR

Total RNA was extracted as described by Srivastava et al. (20) from islets and liver from the same mutants and littermate control mice, treated with DNase I (Ambion, Austin, TX, USA) and reverse transcribed using the Reverse Transcription Reagents kit (Applied Biosystems, Foster City, CA, USA) according to the manufacturer's instructions. Random hexamers were used with $100 \mathrm{ng}$ of total RNA, and reverse transcribed in a $20-\mu$ l reaction. Quantitative PCR (qPCR) assays were performed using the ABI PRISM 7700 Sequence Detection System (TaqMan; Applied Biosystems) with standard fluorescent chemistries and thermal cycling conditions. Primer sequences were designed for each experimental gene's mRNA sequence using Primer Express software (Applied Biosystems) as shown below.

\begin{tabular}{|c|c|c|}
\hline GK Rsl & Forward primer: & $\begin{array}{l}\text { CCTTTTCAGGCTT- } \\
\text { ATACGCTCC }\end{array}$ \\
\hline & Reverse primer: & GGGTGAGCCCGC- \\
\hline IGF 1 & Forward nrimer. & $\begin{array}{l}\text { AGATG } \\
\text { CTACAAAAGCAG- }\end{array}$ \\
\hline & & CCCGCTCT \\
\hline & Reverse primer: & $\begin{array}{l}\text { CTTCTGAGTCTTG- } \\
\text { GGCATGTCA }\end{array}$ \\
\hline NESTIN & Forward primer : & $\begin{array}{l}\text { TTAAGGCCAGAA- } \\
\text { CCCCCAC }\end{array}$ \\
\hline & Reverse primer: & $\begin{array}{l}\text { CTCTGCATTTTTA- } \\
\text { GGATAGGGAGC }\end{array}$ \\
\hline NEURO DI & Forward primer: & $\begin{array}{l}\text { CAATTTGGTCGC- } \\
\text { CGGCT }\end{array}$ \\
\hline & Reverse primer: & $\begin{array}{l}\text { CCGGGTTCTGCT- } \\
\text { CAGGC }\end{array}$ \\
\hline NGN 3 & Forward primer: & $\begin{array}{l}\text { CCCAAGAGCGA- } \\
\text { GTTGGCA }\end{array}$ \\
\hline & Reverse primer: & $\begin{array}{l}\text { TCCCGATCATTG- } \\
\text { GCCTTCT }\end{array}$ \\
\hline PAX 4 & Forward primer: & $\begin{array}{l}\text { GACACACCAGA- } \\
\text { AGAGGGTATCA- } \\
\text { GA }\end{array}$ \\
\hline & Reverse primer: & $\begin{array}{l}\text { AAGTTCAAATCC- } \\
\text { CAGCAACCA }\end{array}$ \\
\hline PTEN & Forward primer: & $\begin{array}{l}\text { TGTGGTCTGCCA- } \\
\text { GCTAAAGGT }\end{array}$ \\
\hline & Reverse primer: & $\begin{array}{l}\text { ACATGAACTTGT- } \\
\text { CCTCCCGC }\end{array}$ \\
\hline
\end{tabular}

\begin{tabular}{|c|c|c|}
\hline GLUT 2 & Forward primer: & $\begin{array}{l}\text { GCCAAGGACCC- } \\
\text { CGTCCT }\end{array}$ \\
\hline & Reverse primer: & $\begin{array}{l}\text { AATTGCAGACCC- } \\
\text { AGTTGCTGA }\end{array}$ \\
\hline IRS 2 & Forward primer : & $\begin{array}{l}\text { GCATCGACTTCC- } \\
\text { TGTCCCA }\end{array}$ \\
\hline & Reverse primer : & $\begin{array}{l}\text { CCTCAAGGTCA- } \\
\text { AAGGGCCTC }\end{array}$ \\
\hline PDX 1 & Forward primer: & $\begin{array}{l}\text { AAATCCACCAA- } \\
\text { AGCTCACGC }\end{array}$ \\
\hline & Reverse primer: & $\begin{array}{l}\text { CTCGGGTTCCGC- } \\
\text { TGTGTAAG }\end{array}$ \\
\hline Anx 7 & Forward primer: & $\begin{array}{l}\text { TCCCCACTGCGG- } \\
\text { GTCA }\end{array}$ \\
\hline & Reverse primer: & $\begin{array}{l}\text { CCTCCTCCCATTG- } \\
\text { GTGGAA }\end{array}$ \\
\hline HPRT & Forward primer & $\begin{array}{l}\text { GTTGGATACAGG- } \\
\text { CCAGACTTTGTTG }\end{array}$ \\
\hline & Reverse primer & $\begin{array}{l}\text { GATTCAACTTGC- } \\
\text { GCTCATCTTAGGC }\end{array}$ \\
\hline
\end{tabular}

Hypoxanthine guanine phosphoribosyl transferase (HPRT) was used as an internal expression control (Applied Biosystems). Primer concentrations were optimized using the TaqMan Universal PCR Master Mix (Applied Biosystems). For each reaction, $7 \mathrm{ng}$ of cDNA was added to optimized primer concentrations, with $25 \mu \mathrm{l}$ of PCR Master Mix. A corresponding well contained $7 \mathrm{ng}$ of cDNA with reaction reagents for the qPCR of HPRT. All reactions were performed in triplicate in separate tubes. Thermal cycling conditions were as specified by the manufacturer: $50^{\circ} \mathrm{C}$ for $2 \mathrm{~min}, 95^{\circ} \mathrm{C}$ for $10 \mathrm{~min}$, and $40 \mathrm{cy}$ cles at $95^{\circ} \mathrm{C}$ for $15 \mathrm{sec}$, ramp to $60^{\circ} \mathrm{C}$ for $1 \mathrm{~min}$.

Relative quantitation of gene expression was performed according to the manufacturer's instructions. Briefly, the threshold cycle $\left(C_{\mathrm{T}}\right)$ was determined for both the experimental gene and HPRT. The following formula was used to calculate the relative amount of each gene in the sample $(X$, mutant islet), normalized to endogenous reference (HPRT) and relative to the amount of each gene in another sample ( $\mathrm{Y}$, littermate control): $2^{-\Delta \Delta \mathrm{CT}}$, where $\Delta C_{\mathrm{T}}$ is the difference in threshold cycles for each gene and HPRT, and $\Delta \Delta C_{\mathrm{T}}$ for sample $X=\Delta C_{\mathrm{T}, \mathrm{X}}-\Delta C_{\mathrm{T}, \mathrm{Y}}$

\section{Results}

Physiologic Responses of Fasted Anx7(+/-) and Control Mice to Pulses of Glucose and Insulin

In anticipation of data showing profound effects of the Anx7(+I-) mutation on nutritional genomics, it seemed important to test whether peripheral effects of the mutation might have consequences for islet function. Glucose tolerance tests were therefore administered to control and Anx7(+/-) mice after a 16-hr overnight fast. As shown in Figure 1A, blood glucose measurements of control and mutant mice at time zero indicate that there is no statistically significant difference between blood glucose levels, 

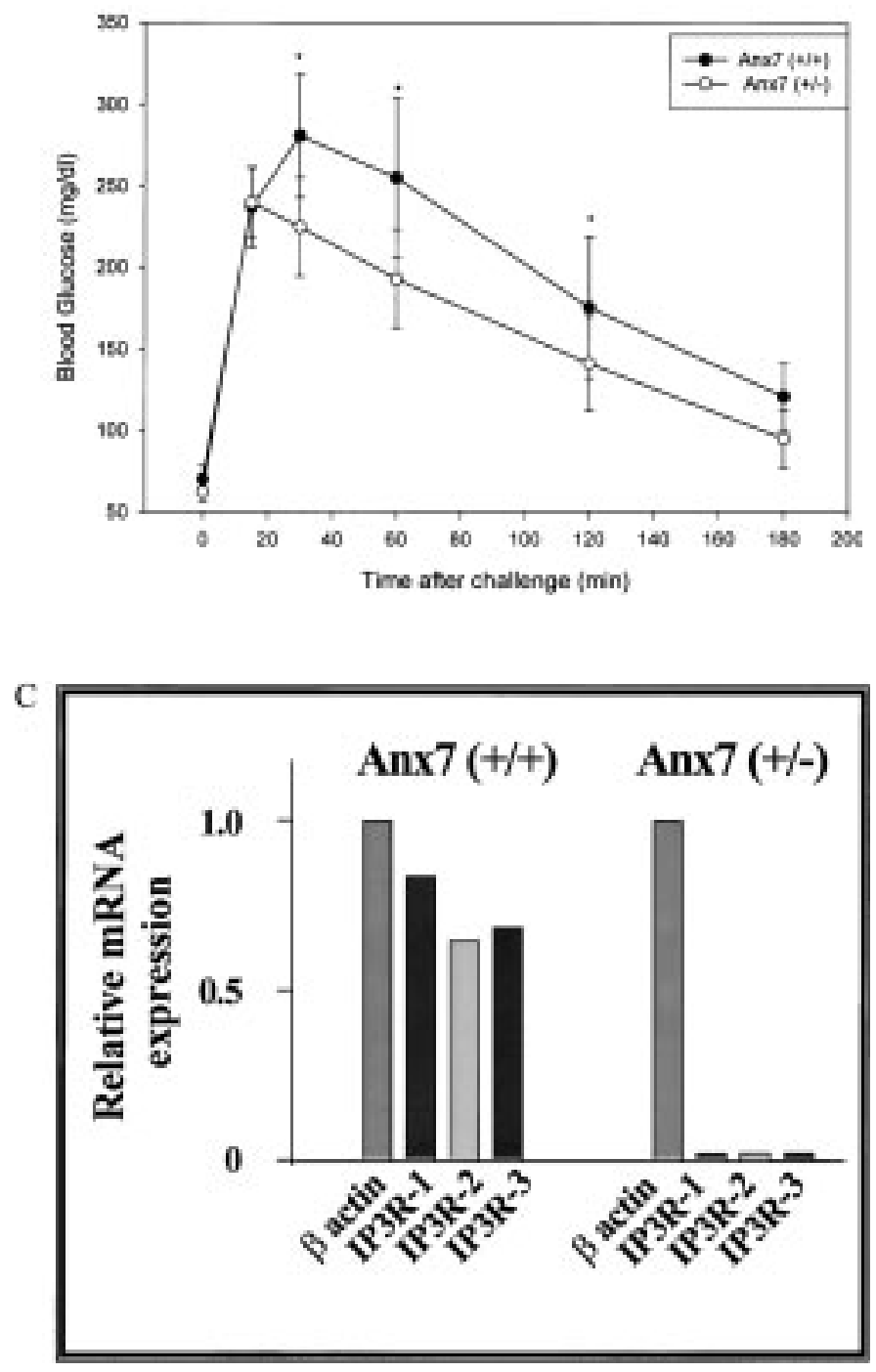

regardless of whether the fed or the fasted states are compared (Table 1). However, the ability of the mutant to reduce a bolus of glucose is significantly more efficient than that of the control mouse. Presumably, the hypertrophic character of the mutant islets and the hyperplastic character of the $\beta$ cells serve to compensate for the low rate of calciumdependent insulin secretion In addition, although there was only a modest and relatively insignificant $\left.{ }^{*} p=0.19\right)$ difference in blood glucoses between fed and fasted controls, there is a significant difference between fed and fasted mutants $(\# p=0.05)$. Finally, while fasting mutant mice have a somewhat lower blood insulin level than fasting controls, these differences do not reach statistical significance.

We considered the possibility that the significantly more robust glucose tolerance test on the part of mutant mice could include peripheral contributions. For example, it is possible that the mutant mice might

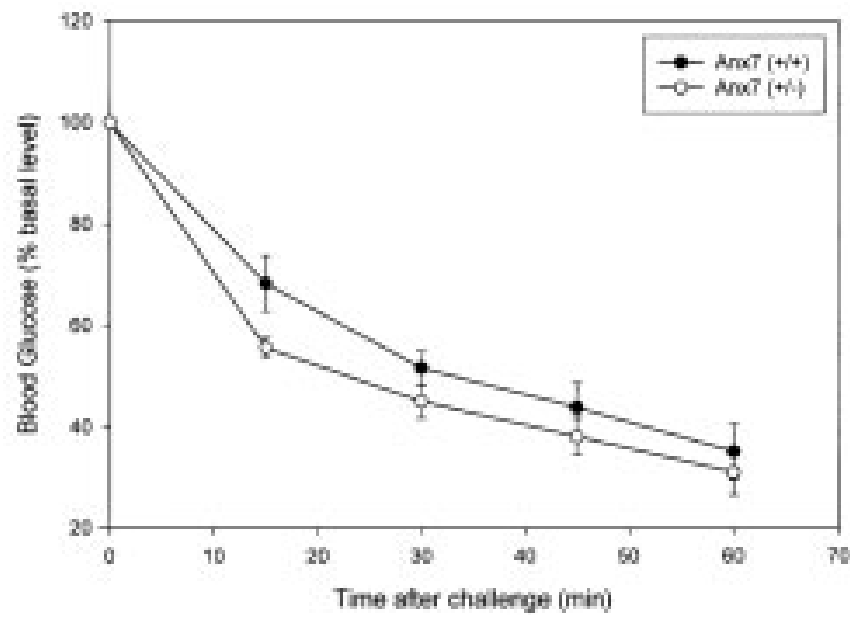

Fig. 1. Physiologic and molecular properties of Anx7(+/-) mice, compared to normal Anx7 $(+/+)$ littermate controls. (A) Glucose tolerance test for Anx7(+/+) and Anx7(+/-) mice. Blood glucose levels were measured in seven pairs of control (a) and anx7 (+/-) (b) knockout mice littermates following a glucose challenge $\left(2 \mathrm{~g} / \mathrm{kg}\right.$ IP) after $24 \mathrm{hr}$ fasting. ${ }^{*} p<0.1$, paired $t$-test versus control, Anx7 $(+/+)$ male littermates. See Table 1 for summary. (B) Insulin tolerance test for Anx7(+/+) and Anx7(+I-) mice. Insulin levels were measured in control (a) and Anx7 (+/-) (b) knockout mice littermates following insulin challenge (1 U/kg IP) without fasting. ${ }^{*} p<0.1 ;{ }^{* *} p<$ 0.05 , paired $t$-test versus control, Anx7 $(+/+)$ male littermates $(n=24$ mice). (C) Inositol-trisphosphate receptor gene expression for Anx7(+/+) and Anx7(+/-) mice. Relative abundance of IP3 receptor types in control and mutant mice by RT-PCR. PCR conditions and the primer pairs used are as described in Materials and Methods.

be somewhat more sensitive to insulin than the controls. To test this hypothesis, we performed insulin tolerance tests on fed animals. As shown in Figure 1B, the Anx7(+/-) mice are indeed slightly but significantly more sensitive to insulin than control animals.

Other peripheral contributions to homeostasis could include the set of classical counter-regulatory hormones such as glucagons, IGF-1, growth hormone (GH), and corticosterone. To test this hypothesis, we collected samples of serum from animals fasted overnight, and assayed for these hormones. As shown in Table 2, none of these hormones differ significantly when comparing control and mutant animals. In addition, no differences are noted for either testosterone levels (see Table 2), or epinephrine content of intact adrenal glands (35 animals, data not shown). We interpret these data to indicate that reduced insulin resistance may make a modest peripheral contribution to the appearance of an 
Table 1. Blood glucose and insulin levels in male Anx7(+/-) and control mice

\begin{tabular}{|c|c|c|c|c|c|c|}
\hline & \multicolumn{4}{|c|}{ Fasted Mice, 16 hr } & \multirow{2}{*}{\multicolumn{2}{|c|}{$\begin{array}{l}\text { Fed Mice, ad Libidum } \\
\text { Blood Glucose (mg/dl) }\end{array}$}} \\
\hline & \multicolumn{2}{|c|}{ Blood Glucose (mg/dl) } & \multicolumn{2}{|c|}{ Blood Insulin (ng/ml) } & & \\
\hline & $\operatorname{Anx} 7(+/+)^{*}$ & $\operatorname{Anx7}(+/-)^{\#}$ & $\operatorname{Anx} 7(+/+)$ & $\operatorname{Anx} 7(+/-)$ & $\operatorname{Anx} 7(+/+)^{*}$ & $\operatorname{Anx} 7(+/-)^{\#}$ \\
\hline Average & 103.0 & 99.7 & 0.96 & 0.79 & 113.4 & 115.6 \\
\hline SEM & 3.6 & 2.1 & 0.16 & 0.08 & 7.0 & 7.7 \\
\hline$n$ & 88 & 88 & 27 & 27 & 7 & 7 \\
\hline$p$ & \multicolumn{2}{|c|}{$>0.1$} & \multicolumn{2}{|c|}{$>0.1$} & \multicolumn{2}{|c|}{$>0.1$} \\
\hline
\end{tabular}

${ }^{*} p=0.19$

${ }^{\#} p=0.05$

Blood glucose levels were measured after $24 \mathrm{hr}$ fasting using calibrated glucometer and insulin levels were obtained by the radioimmunoassay using ${ }^{125}[\mathrm{I}]$-bovine insulin and a guinea pig anti-porcine insulin antibody for detection. These data represent studies on seven mutant male mice and their normal littermate controls.

enhanced GTTs by mutant animals, and to the appearance of physiologic intactness at the organismic level. However, there do not appear to be significant endocrine contributions to metabolic regulation of glucose by peripheral organs. Although these data are by no means exhaustive, they are sufficiently powered to suggest that these specific peripheral influences are probably not responsible for differences in mutant islet structure and function consequent to the previously identified calcium signaling deficits.

Expression of $I P_{3}$ Receptor Type 3 mRNA Expression in Anx7(+/-) and Control Islets

As indicated, the molecular response of $\beta$ cells in isolated islets of Langerhans to glucose is associated with a biosynthetic pulse of $\mathrm{IP}_{3}$ receptor type 3 (ITPR3) messenger RNA, followed by synthesis of ITPR3 protein. We have reported previously that IPTR3 protein is constitutively low in Anx7(+I-) islets (20). Goping et al. (21) have repeated this study on a separate set of mutant Anx7(+/-) mouse islets, with similar results. We therefore inquired whether Anx7 mouse islets were able to synthesize ITPR3 message in vivo. As shown in Figure 1C, islets from normal littermate control mice in the fed state express substantial amounts of IPTR3 message, whereas islets from Anx7(+/-) mice express virtually no IPTR3 message whatsoever. We conclude that the mechanism of reduction of IPTR3 protein expression in the Anx7(+/-) mouse $\beta$ cell is due to suppression of IPTR3 gene transcription.

Table 2. Hormone levels in male Anx7(+/-) and control mice

\begin{tabular}{|c|c|c|c|c|c|c|c|c|c|c|}
\hline & \multicolumn{2}{|c|}{$\begin{array}{c}\text { Glucagon } \\
(\mathrm{pg} / \mathrm{ml})\end{array}$} & \multicolumn{2}{|c|}{$\begin{array}{l}\text { IGF-1 } \\
\text { (ng/ml) }\end{array}$} & \multicolumn{2}{|c|}{$\begin{array}{c}\mathbf{G H} \\
(\mathbf{n g} / \mathbf{m l})\end{array}$} & \multicolumn{2}{|c|}{$\begin{array}{c}\text { Corticosterone } \\
(\mathrm{ng} / \mathrm{ml})\end{array}$} & \multicolumn{2}{|c|}{$\begin{array}{l}\text { Testosteron } \\
(\mathrm{ng} / \mathrm{ml})\end{array}$} \\
\hline & $\begin{array}{l}\operatorname{Anx7} \\
(+/+)\end{array}$ & $\begin{array}{l}\text { Anx7 } \\
(+/-)\end{array}$ & $\begin{array}{l}\operatorname{Anx7} \\
(+/+)\end{array}$ & $\begin{array}{l}\operatorname{Anx7} \\
(+/-)\end{array}$ & $\begin{array}{l}\text { Anx7 } \\
(+/+)\end{array}$ & $\begin{array}{l}\operatorname{Anx7} \\
(+/-)\end{array}$ & $\begin{array}{l}\operatorname{Anx7} \\
(+/+)\end{array}$ & $\begin{array}{l}\operatorname{Anx7} \\
(+/-)\end{array}$ & $\begin{array}{l}\operatorname{Anx7} \\
(+/+)\end{array}$ & $\begin{array}{l}\operatorname{Anx7} \\
(+/-)\end{array}$ \\
\hline Average & 48.61 & 56.31 & 288 & 287 & 0.93 & 0.82 & 266.07 & 193.38 & 0.54 & 0.66 \\
\hline SEM & 3.06 & 4.86 & 23 & 9 & 0.14 & 0.11 & 49.41 & 24.22 & 0.1 & 0.2 \\
\hline$n$ & 4 & 4 & 2 & 26 & 21 & 20 & 14 & 13 & 6 & 4 \\
\hline$p$ & \multicolumn{2}{|c|}{$>0.1$} & \multicolumn{2}{|c|}{$>0.1$} & \multicolumn{2}{|c|}{$>0.1$} & \multicolumn{2}{|c|}{$>0.1$} & \multicolumn{2}{|c|}{$>0.1$} \\
\hline
\end{tabular}

Seven littermate pairs of male and female animals were used for these analyses. IGF-1 measurements were measured by a double antibody radio-immunoassay using recombinant human IGF-1 (Endocrine Sciences, San Diego, CA) and anti-human IGF-1 serum after removal of binding proteins from a $5 \mu \mathrm{l}$ aliquot of serum using Sep-Pak C18 reverse phase cartridge (Millipore). Corticosterone was measured using ${ }^{125} \mathrm{I}$-corticosterone and anti-corticosterone antibody. Glucagon, growth hormone and testosterone were measured by radioimmunoassay using their respective antibodies. 
Comparative Genomics of Islets From Anx7(+/-) and $(+/+)$ Mice in the Fed or Fasted States

In an effort to gain a global perspective on expression of genes besides IPTR 3 that are affected by the Anx7(+/-) mutation, we turned to cDNA microarray technology. Inasmuch as the principal function of the islet is to respond to and control nutrient conditions in the intact animal, we used a nutritional paradigm to elicit genomic differences. Anx7(+/-) and $A n \times 7(+/+)$ mice were systematically exposed to a regimen of either food and water, ad libidum, or to a terminal $16 \mathrm{hr}$ without food. Following sacrifice at exactly 9 AM, the islets were quickly prepared and mRNA isolated for subsequent analysis. Out of $\mathbf{5 8 8}$ genes queried, we were able to gain useful data on 400 genes. As shown in Figure 2 (blue circles), there is a substantial difference between gene expression in control islets from animals allowed food and those fasted overnight prior to sacrifice. The dashed black diagonal line indicates the location of genes whose expression is identical in the two nutritional states. It is clear that although there are many genes arranged along the diagonal, there are quite a few that are some distance away. Data for Anx7(+/-) islets stand in stark contrast to this situation in

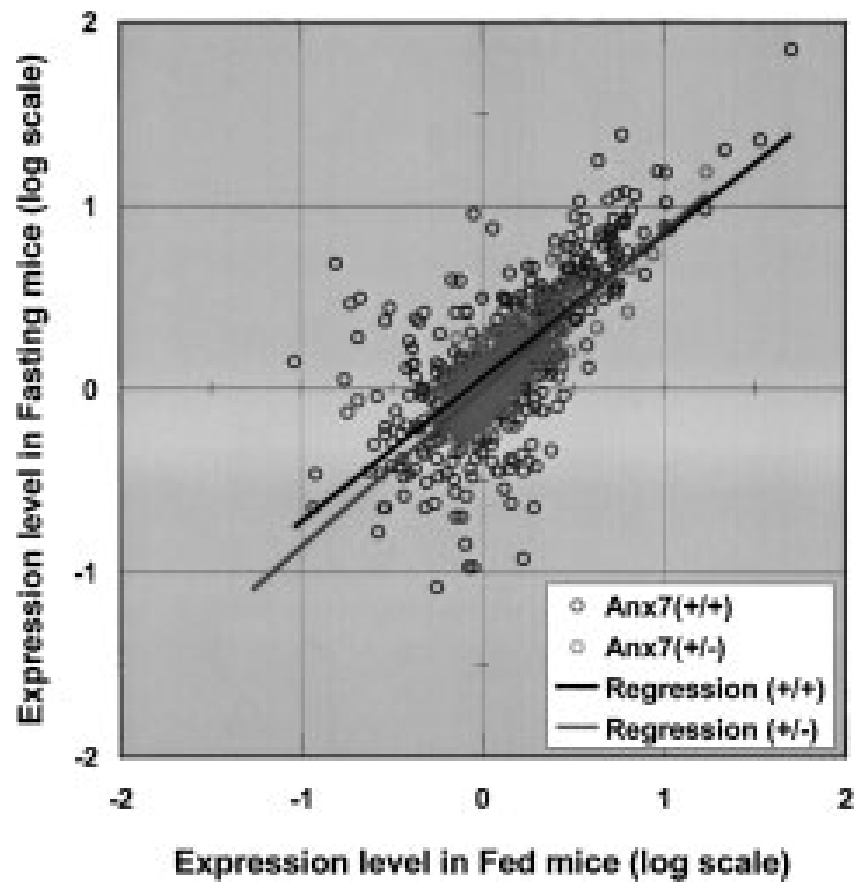

Fig. 2. Global gene expression in islets of fed and fasted for Anx7(+/+) and Anx7(+/-) mice. Gene expression levels plotted as a function of the expression levels of the respective genes in the fed and fasted state are compared between Anx7(+/-) (red) and Anx7 $(+/+)$ (blue) mice. The dashed black diagonal line indicates the location of genes whose expression is identical in the fed or fasted states. This graph is an average of duplicate assays of individual islet preparations from male Anx $(+/-)$ mice and their cognate Anx7 $(+/+)$ normal littermate controls. Four mice of each genotype were used for the experiment. control islets in that the majority of genes are much closer to the diagonal (Fig. 2, red circles). This means that most of the islet genes in mutant animals are relatively insensitive to the nutritional state. We therefore have an opportunity to mine out those islet genes whose expression is specifically affected by nutritional history in controls, and which are suppressed in the Anx7(+/-) mutants.

\section{Application of the GRASP Algorithm to Identify Differentially Acting Islet Genes}

Using the GRASP algorithm we are able to identify genes whose expression significantly differs when comparing the consequences of the fed or fasting states on either the control or mutant animals. The strategy we employ is to calculate an average change for all genes in the array, and to identify those genes that change by more than two standard deviations from this average. As pointed out in Figure 2, the distribution of genes from the mutant islets are much tighter around the diagonal than those for control animals. Therefore, in the case of the mutant islet data we take care to identify those genes whose variation is more than 2 SDs from the mutant average. Using this approach we are able to identify 30 genes each from comparisons of fed and fasting states in control and mutant islets. These data are summarized in Table 3. The list contains 52 genes due to overlap between the two conditions. Many, but not all, of these affected genes have a substantial history of association with the development and function of islet $\beta$ cells.

\section{HELP Diagrams to Compare the Actions of Differentially Expressed Genes in Control Islets With Actions of Those Same Genes in Mutant Islets}

The genomic experiments in this paper illustrate an inherently complex phenomenon-namely, the effect of knocking out a gene (Anx7) on the response to a given stress (fasting) on global cell expression. In attempting to display these results in a simple graphical fashion, our problem is to show, for each gene, four different entities simultaneously on a two dimensional graph. To solve this problem we devised a new form of graph shown in Figures 3 and 4. We call this graph a HELP diagram, standing for heliometric plot, (from heliometer, a device for measuring angles between celestial bodies). The axes in a HELP diagram are the expression levels under control ( $x$ axis) and stress ( $y$-axis) conditions with vectors linking the expression levels in the normal (control) to the experimental (knockout) conditions. Thus each vector renders a visual display of four entities. We find that to compare the results for many genes it is helpful to normalize the expression level of each gene to the control (fed, $+/+$ ) level. This process makes all vectors start on a point along the $y$-axis. The usefulness of this vectorial display is that the length of the vector is related to the magnitude of the effect of the Anx7(+/-) knockout on the response of a specific gene to the fasting stress. In addition, the 
Table 3. Effect of fasting stress and Anx7 knockout on gene expression in mouse pancreatic islets

\begin{tabular}{|c|c|c|c|c|c|c|c|}
\hline \multirow[b]{2}{*}{ Symbol } & \multirow[b]{2}{*}{ Gene Name } & \multicolumn{4}{|c|}{ Expression Levels } & \multicolumn{2}{|c|}{$\begin{array}{l}\text { Ratio (Fast/Fed), } \\
\text { Fold Increase }(\uparrow) \\
\text { or Decrease }(\downarrow)\end{array}$} \\
\hline & & $\begin{array}{l}\text { Con, } \\
\text { Fed }\end{array}$ & $\begin{array}{l}\text { Con, } \\
\text { Fasting }\end{array}$ & $\begin{array}{l}\text { K/O, } \\
\text { Fed }\end{array}$ & $\begin{array}{l}\text { K/O, } \\
\text { Fasting }\end{array}$ & Con & $\mathbf{K} / \mathbf{O}$ \\
\hline HR21SP & $\begin{array}{l}\text { DNA double-strand break repair RAD21 } \\
\text { homolog; HR2 1SP; PW29 }\end{array}$ & 0.16 & 4.82 & 0.77 & 0.65 & $31.0(\uparrow)$ & $1.2(\downarrow)$ \\
\hline FST & $\begin{array}{l}\text { Follistatin precursor (FST); activin-binding } \\
\text { protein }\end{array}$ & 0.19 & 2.91 & 0.79 & 0.93 & $15.5(\uparrow)$ & $1.2(\uparrow)$ \\
\hline mHR23A & $\begin{array}{l}\text { RAD23 UV excision repair protein homolog A } \\
\text { (mHR23A; RAD23A) }\end{array}$ & 0.90 & 8.95 & 1.04 & 0.83 & $10.0(\uparrow)$ & $1.3(\downarrow)$ \\
\hline mGCM1 & Glial cells missing gene homolog (mGCMl) & 1.67 & 0.12 & 1.13 & 0.77 & $14.2(\downarrow)$ & $1.5(\downarrow)$ \\
\hline GSTT1 & $\begin{array}{l}\text { Gluthathione } S \text {-transferase theta } 1 \\
\text { (GST theta } 1 ; \text { GSTT1) }\end{array}$ & 0.09 & 1.40 & 0.72 & 1.24 & $15.3(\uparrow)$ & $1.7(\uparrow)$ \\
\hline ELF1 & $\begin{array}{l}\text { ets-Related transcription factor; E74-like factor } 1 \\
\text { (ELF1) }\end{array}$ & 0.84 & 0.11 & 0.89 & 0.94 & $7.9(\downarrow)$ & $1.1(\uparrow)$ \\
\hline SCYB9 & $\begin{array}{l}\text { Small inducible cytokine B subfamily member } 9 \\
\text { (SCYB9); monoking induced by gamma } \\
\text { interferon (MIG) }\end{array}$ & 0.29 & 2.34 & 0.86 & 0.86 & $8.0(\uparrow)$ & $1.0(\downarrow)$ \\
\hline MLHI & $\begin{array}{l}\text { MLHI DNA mismatch repair protein; MutL } \\
\text { homolog }\end{array}$ & 0.68 & 3.92 & 0.85 & 0.64 & $5.8(\uparrow)$ & $1.3(\downarrow)$ \\
\hline CRABP2 & $\begin{array}{l}\text { Cellular retinioc acid-binding protein II } \\
\text { (CRABO-II;CRABP2) }\end{array}$ & 0.89 & 0.11 & 0.87 & 0.78 & $8.4(\downarrow)$ & $1.1(\downarrow)$ \\
\hline FGF9 & Fibroblast growth factor 9 & 0.31 & 2.76 & 0.75 & 0.99 & $9.0(\uparrow)$ & $1.3(\uparrow)$ \\
\hline TSN & Translin (TSN) & 1.15 & 7.52 & 1.09 & 1.07 & $6.5(\uparrow)$ & $1.0(\downarrow)$ \\
\hline GDNF & $\begin{array}{l}\text { Glial cell line-derived neurotropic factor precursor } \\
\text { (GDNF) }\end{array}$ & 0.43 & 2.41 & 0.88 & 0.74 & $5.6(\uparrow)$ & $1.2(\downarrow)$ \\
\hline ITGAM & $\begin{array}{l}\text { Cell-surface glycoprotein MAC-1 alpha subunit } \\
\text { precursor; CR-3 alpha subunit; CD 11B antigen; } \\
\text { leukocyte adhesion receptor MO1; integrin } \\
\text { alpha-M (ITGAM) }\end{array}$ & 0.21 & 1.91 & 0.64 & 0.90 & $9.3(\uparrow)$ & $1.4(\uparrow)$ \\
\hline TFDP1 & $\begin{array}{l}\text { Transcription factor E2F dimerization partner } 1 \\
\text { (TFDP1); DRTF1 polypeptide } 1\end{array}$ & 1.91 & 0.22 & 1.32 & 0.92 & $8.6(\downarrow)$ & $1.4(\downarrow)$ \\
\hline GADD 153 & $\begin{array}{l}\text { Growth arrest and DNA damage-inducible } \\
\text { protein } 153 \text { (GADD153); DNA damage-inducible } \\
\text { transcript } 3 \text { (DDIT3); C/EBP-homologous } \\
\text { protein (CHOP) }\end{array}$ & 0.21 & 3.12 & 0.72 & 1.89 & $14.7(\uparrow)$ & $2.6(\uparrow)$ \\
\hline SPI3 & Serine proteinase inhibitor 3 (SPI3) & 1.44 & 0.24 & 1.01 & 0.91 & $6.1(\downarrow)$ & $1.1(\downarrow)$ \\
\hline GPIA & $\begin{array}{l}\text { Platelet membrane glycoprotein IA precursor } \\
\text { (GPIA); integrin alpha } 2 \text { (ITGA); collagen } \\
\text { receptor; VLA2 alpha subunit; CD } 49 \mathrm{~B} \text { antigen }\end{array}$ & 0.56 & 0.08 & 0.80 & 0.63 & $6.8(\downarrow)$ & $1.3(\downarrow)$ \\
\hline XPG & $\begin{array}{l}\text { Xeroderma pigmentosum group G complementing } \\
\text { protein (XPG); X-ray repair-complementing } \\
\text { defective repair in Chinese hamster cells } 5 \\
\text { (XRCC5) }\end{array}$ & 0.75 & 3.89 & 0.96 & 0.94 & $5.2(\uparrow)$ & $1.0(\downarrow)$ \\
\hline PML & Promyelocytic leukemia gene (PML) & 0.80 & 0.14 & 0.94 & 0.80 & $5.7(\downarrow)$ & $1.2(\downarrow)$ \\
\hline hHR23B & $\begin{array}{l}\text { UV excision repair protein RAD23 homolog B } \\
\text { (hHR23B); xeroderma pigmentosum group C } \\
\text { repair-complementing complex 58-kDa protein } \\
\text { (XPC repair-complementing complex 58-kDa } \\
\text { protein) }\end{array}$ & 4.35 & 17.53 & 1.97 & 1.69 & $4.0(\uparrow)$ & $1.2(\downarrow)$ \\
\hline
\end{tabular}


Table 3. (Continued)

\begin{tabular}{|c|c|c|c|c|c|c|c|}
\hline \multirow[b]{2}{*}{ Symbol } & \multirow[b]{2}{*}{ Gene Name } & \multicolumn{4}{|c|}{ Expression Levels } & \multicolumn{2}{|c|}{$\begin{array}{l}\text { Ratio (Fast/Fed), } \\
\text { Fold Increase }(\uparrow) \\
\text { or Decrease }(\downarrow)\end{array}$} \\
\hline & & $\begin{array}{l}\text { Con, } \\
\text { Fed }\end{array}$ & $\begin{array}{l}\text { Con, } \\
\text { Fasting }\end{array}$ & $\begin{array}{l}\text { K/O, } \\
\text { Fed }\end{array}$ & $\begin{array}{l}\text { K/O, } \\
\text { Fasting }\end{array}$ & Con & $\mathbf{K} / \mathbf{O}$ \\
\hline NFIA & Nuclear factor I/A (NFIA); NFIB & 1.68 & 0.35 & 1.05 & 1.01 & $4.8(\downarrow)$ & $1.0(\downarrow)$ \\
\hline DAD 1 & Defender against cell death 1 protein (DADl) & 0.17 & 1.12 & 0.71 & 1.06 & $6.4(\uparrow)$ & $1.5(\uparrow)$ \\
\hline PAX 6 & $\begin{array}{l}\text { Paired box protein } 6 \text { (PAX6); small eye protein } \\
\text { (SEY) }\end{array}$ & 0.77 & 0.20 & 0.97 & 1.07 & $3.9(\downarrow)$ & $1.1(\uparrow)$ \\
\hline TEK & $\begin{array}{l}\text { Endothelial-specific receptor tyrosine kinase } \\
\text { (TEK); tunica interna endothelial cell kinase } 2 \\
\text { (TIE2); adhesion structures-linked tyrosine kinase } \\
\text { (HYK); angiopoietin } 1 \text { receptor precursor }\end{array}$ & 1.32 & 0.28 & 1.09 & 1.00 & $4.7(\downarrow)$ & $1.1(\downarrow)$ \\
\hline GRIN2 & $\begin{array}{l}\text { Glutamate receptor subunit epsilon } 2 \text { precursor } \\
\text { (GRIN2); N-methyl D-aspartate receptor subtype } \\
\text { 2B (NMDAR2B; NR2B) }\end{array}$ & 0.21 & 0.86 & 0.63 & 0.68 & $4.2(\uparrow)$ & $1.1(\uparrow)$ \\
\hline $\mathrm{T}-\beta 2$ & Transducin beta-2 subunit & 0.71 & 0.20 & 0.79 & 0.81 & $3.6(\downarrow)$ & $1.0(\uparrow)$ \\
\hline A-RAF & A-raf proto-oncogene & 1.97 & 0.38 & 1.26 & 0.85 & $5.2(\downarrow)$ & $1.5(\downarrow)$ \\
\hline GATA3 & GATA-binding protein 3 (GATA3) & 2.40 & 0.46 & 1.48 & 0.97 & $5.2(\downarrow)$ & $1.5(\downarrow)$ \\
\hline TDAG5 1 & T-cell death-associated gene 51 (TDAG51) & 0.18 & 0.74 & 0.85 & 1.04 & $4.1(\uparrow)$ & $1.2(\uparrow)$ \\
\hline 5 HT1Е- $\beta$ & $\begin{array}{l}\text { 5-Hydroxytryptamine receptor } 1 \mathrm{E} \text { receptor beta } \\
\text { (5HTIE-beta; HTR IE-beta); serotonin receptor }\end{array}$ & 0.26 & 0.91 & 0.72 & 0.78 & $3.5(\uparrow)$ & $1.1(\uparrow)$ \\
\hline SMBP2 & DNA-binding protein SMBP2 & 1.81 & 0.40 & 1.53 & 1.01 & $4.5(\downarrow)$ & $1.5(\downarrow)$ \\
\hline NCAD & $\begin{array}{l}\text { Cadherin } 2 \text { (CDH2); neural-cadherin precursor } \\
\text { (N-cadherin; NCAD) }\end{array}$ & 0.48 & 2.61 & 0.68 & 1.25 & $5.4(\uparrow)$ & $1.8(\uparrow)$ \\
\hline TNFR2 & $\begin{array}{l}\text { Tumor necrosis factor receptor superfamily } \\
\text { member 1B2 (TNFRSF1B2); tumor necrosis factor } \\
\text { receptor } 2 \text { precursor (TNFR2) }\end{array}$ & 0.45 & 2.31 & 0.89 & 1.60 & $5.1(\uparrow)$ & $1.8(\uparrow)$ \\
\hline SLAP & $\begin{array}{l}\text { SLAP; } s r c \text {-like adapter protein; Eck receptor } \\
\text { tyrosine kinase-associated }\end{array}$ & 0.12 & 0.34 & 0.72 & 0.79 & $2.8(\uparrow)$ & $1.1(\uparrow)$ \\
\hline PPG & Preproglucagon & 1.67 & 1.99 & 2.74 & 1.31 & $1.2(\uparrow)$ & $2.1(\downarrow)$ \\
\hline AA3R & Adenosine A3 receptor & 0.29 & 0.56 & 0.82 & 0.71 & $1.9(\uparrow)$ & $1.1(\downarrow)$ \\
\hline HGF & Hepatocyte growth factor (HGF) & 0.48 & 0.22 & 0.80 & 0.80 & $2.2(\downarrow)$ & $1.0(\uparrow)$ \\
\hline PTP & Protein tyrosine phosphatase & 0.38 & 0.62 & 1.02 & 0.80 & $1.6(\uparrow)$ & $1.3(\downarrow)$ \\
\hline SIM2 & Single-minded 2 (SIM2) & 5.88 & 24.21 & 2.55 & 5.57 & $4.1(\uparrow)$ & $2.2(\uparrow)$ \\
\hline FYN & Fyn proto-oncogene & 0.25 & 0.49 & 0.80 & 0.87 & $2.0(\uparrow)$ & $1.1(\uparrow)$ \\
\hline MGSTl & $\begin{array}{l}\text { Microsomal glutathione S-transferase } \\
\text { (MGST1; GST12) }\end{array}$ & 0.81 & 2.65 & 0.92 & 1.75 & $3.2(\uparrow)$ & $1.9(\uparrow)$ \\
\hline ЕРНB2 & Eph receptor B2 & 0.24 & 0.35 & 0.82 & 0.74 & $1.5(\uparrow)$ & $1.1(\downarrow)$ \\
\hline VEGF & $\begin{array}{l}\text { Vascular endothelial growth factor precursor } \\
\text { (VEGF); vascular permeability factor (VPF) }\end{array}$ & 0.29 & 0.61 & 0.96 & 1.24 & $2.1(\uparrow)$ & $1.3(\uparrow)$ \\
\hline CCN2 & G2/mitotic-specific cyclin B1(CCNB1;CYCBI);CCN2 & 2.82 & 0.92 & 1.49 & 0.77 & $3.1(\downarrow)$ & $1.9(\downarrow)$ \\
\hline KRT18 & $\begin{array}{l}\text { Type I cytoskeletal keratin } 18 \text { (KRT1-18; KRT18); } \\
\text { cytokeratin 18; cytokeratin endo B; keratin D } \\
\text { (KERD) }\end{array}$ & 5.09 & 6.80 & 2.41 & 5.08 & $1.3(\uparrow)$ & $2.1(\uparrow)$ \\
\hline GRA & Glucocorticoid receptor form A & 0.12 & 0.22 & 0.62 & 0.76 & $1.9(\uparrow)$ & $1.2(\uparrow)$ \\
\hline HSP84 & $\begin{array}{l}\text { Heat shock } 84-k D a \text { protein (HSP84); HSP90 } \\
\text { beta HSPCB; tumor-specific transplantation } \\
\text { 84-kDA antigen (TSTA) }\end{array}$ & 1.09 & 1.32 & 1.01 & 1.70 & $1.2(\uparrow)$ & $1.7(\uparrow)$ \\
\hline
\end{tabular}


Table 3. (Continued)

\begin{tabular}{|c|c|c|c|c|c|c|c|}
\hline \multirow[b]{2}{*}{ Symbol } & \multirow[b]{2}{*}{ Gene Name } & \multicolumn{4}{|c|}{ Expression Levels } & \multicolumn{2}{|c|}{$\begin{array}{l}\text { Ratio }(\text { Fast/Fed), } \\
\text { Fold Increase }(\uparrow) \\
\text { or Decrease }(\downarrow)\end{array}$} \\
\hline & & $\begin{array}{l}\text { Con, } \\
\text { Fed }\end{array}$ & $\begin{array}{l}\text { Con, } \\
\text { Fasting }\end{array}$ & $\begin{array}{l}\text { K/O, } \\
\text { Fed }\end{array}$ & $\begin{array}{l}\mathrm{K} / \mathrm{O}, \\
\text { Fasting }\end{array}$ & Con & $\mathbf{K} / \mathbf{O}$ \\
\hline SCYB2 & $\begin{array}{l}\text { Small inducible cytokine B2 (SCYB2); macrophage } \\
\text { inflamatory protein } 2 \text { alpha (MIP2-alpha; MIP2A) }\end{array}$ & 1.40 & 1.80 & 1.12 & 2.02 & $1.3(\uparrow)$ & $1.8(\uparrow)$ \\
\hline SP2 & $\begin{array}{l}\text { U2 small nuclear ribonucleoprotein auxiliary } \\
\text { factor } 35-\mathrm{kDa} \text { subunit-related protein } 1 \\
\text { (U2AF1-RSI); SP2 }\end{array}$ & 6.16 & 8.21 & 2.86 & 5.19 & $1.3(\uparrow)$ & $1.8(\uparrow)$ \\
\hline CCNAl & G2/mitotic-specific cyclin Al (CCNA1) & 16.95 & 9.52 & 6.35 & 2.63 & $1.8(\downarrow)$ & $2.4(\downarrow)$ \\
\hline BRCA2 & $\begin{array}{l}\text { Breast cancer type } 2 \text { susceptibility protein } \\
\text { (BRCA2) }\end{array}$ & 21.64 & 19.95 & 6.50 & 4.52 & $1.1(\downarrow)$ & $1.4(\downarrow)$ \\
\hline UBE2B & $\begin{array}{l}\text { Ubiquitin-conjugating enzyme E2 } 17-\mathrm{kDa}(\mathrm{UBE} 2 \mathrm{~B}) \text {; } \\
\text { ubiquitin-protein ligase; ubiquitin carrier protein; } \\
\text { HR6B }\end{array}$ & 6.98 & 11.35 & 2.09 & 2.59 & $1.6(\uparrow)$ & $1.2(\uparrow)$ \\
\hline CRP3 & $\begin{array}{l}\text { CCAAT/enhancer-binding protein delta } \\
\text { (C/EBP delta; CEBPD); C/EBP-related } \\
\text { protein } 3 \text { (CRP3) }\end{array}$ & 2.60 & 3.61 & 1.64 & 2.92 & $1.4(\uparrow)$ & $1.8(\uparrow)$ \\
\hline OSM & Oncostatin M (OSM) & 5.31 & 3.52 & 3.03 & 1.58 & $1.5(\downarrow)$ & $1.9(\downarrow)$ \\
\hline BCLW & $\begin{array}{l}\text { B-cell lymphoma protein W(BCLW); BCL2-like } \\
\text { protein } 2 \text { (BCL2L2) }\end{array}$ & 0.27 & 0.16 & 0.83 & 0.62 & $1.6(\downarrow)$ & $1.3(\downarrow)$ \\
\hline GRase & Glutathione reductase (GRase; GSR; GR) & 0.29 & 0.22 & 0.82 & 0.76 & $1.3(\downarrow)$ & $1.1(\downarrow)$ \\
\hline APC & adenomatous polyposis coli protein (APC) & 6.49 & 3.53 & 2.76 & 1.53 & $1.6(\downarrow)$ & $1.8(\downarrow)$ \\
\hline MADHI & $\begin{array}{l}\text { Mothers against decapentaplegic homolog } 1 \\
\text { (MADH1; mSMAD 1); TGF-beta signaling } \\
\text { protein } 1 \text { (BSP1) }\end{array}$ & 5.64 & 3.73 & 2.52 & 1.52 & $1.5(\downarrow)$ & $1.7(\downarrow)$ \\
\hline GPI & $\begin{array}{l}\text { Glucose-6-phosphate isomerase (GPI); } \\
\text { phosphoglucose isomerase (PGI); } \\
\text { phosphohexoseisomerase(PHI); } \\
\text { neuroleukin (NLK) }\end{array}$ & 33.89 & 22.65 & 8.75 & 5.39 & $1.5(\downarrow)$ & $1.6(\downarrow)$ \\
\hline ATF3 & Activating transcription factor 3 (ATF3); LRG-2 1 & 0.34 & 0.66 & 0.75 & 1.39 & $1.9(\uparrow)$ & $1.9(\uparrow)$ \\
\hline APOJ & $\begin{array}{l}\text { Clusterin precursor (CLU); clustrin; } \\
\text { apolipoprotein J (APOJ); sulfated glycoprotein } 2 \\
\text { (SGP2; mSGP2) }\end{array}$ & 1.58 & 2.74 & 1.12 & 2.02 & $1.7(\uparrow)$ & $1.8(\uparrow)$ \\
\hline
\end{tabular}

Effect of the fasting $v$ s. fed paradigm on significantly and differentially affected expression of genes associated with development and differentiation of islets in the control and Anx7(+/-) knockout mouse.

angle of the vector delineates information about the mode of the effect. Thus, a horizontal vector shows an effect of the mutation only on the expression in the fed state while a vertical vector depicts an effect only in the fasting state. Conversely a vector parallel to the main diagonal shows a comparable effect in both states. These different modes in which the knockout of Anx7 affects expression levels are sorted in Figures 3 and 4 into the following groups (i.e., angular classes): (A) genes affected only in the fasting state (displaying vertical vectors); (B) genes affected only in the fed state (horizontal vectors); (C) genes affected equally in the fed and the fasted states (vectors parallel to the main diagonal); and (D) genes forced by the mutation to express exactly as in the fed state, regardless of feeding history (vectors of genes moving toward the main diagonal).

Genes in Figure 3 are those most significantly affected by the mutation. Genes in Figure 4 are those most significantly affected by fasting. There is substantial overlap. The central vertical axis at the $(0,0)$ point in the HELP diagram in Figures 3 and 4 represents the ratio of fed-to-fasted gene expression for significantly affected genes in the control mouse islets. Each gene is anchored there on the central vertical axis by a small symbol. The expression of that gene in the mutant 

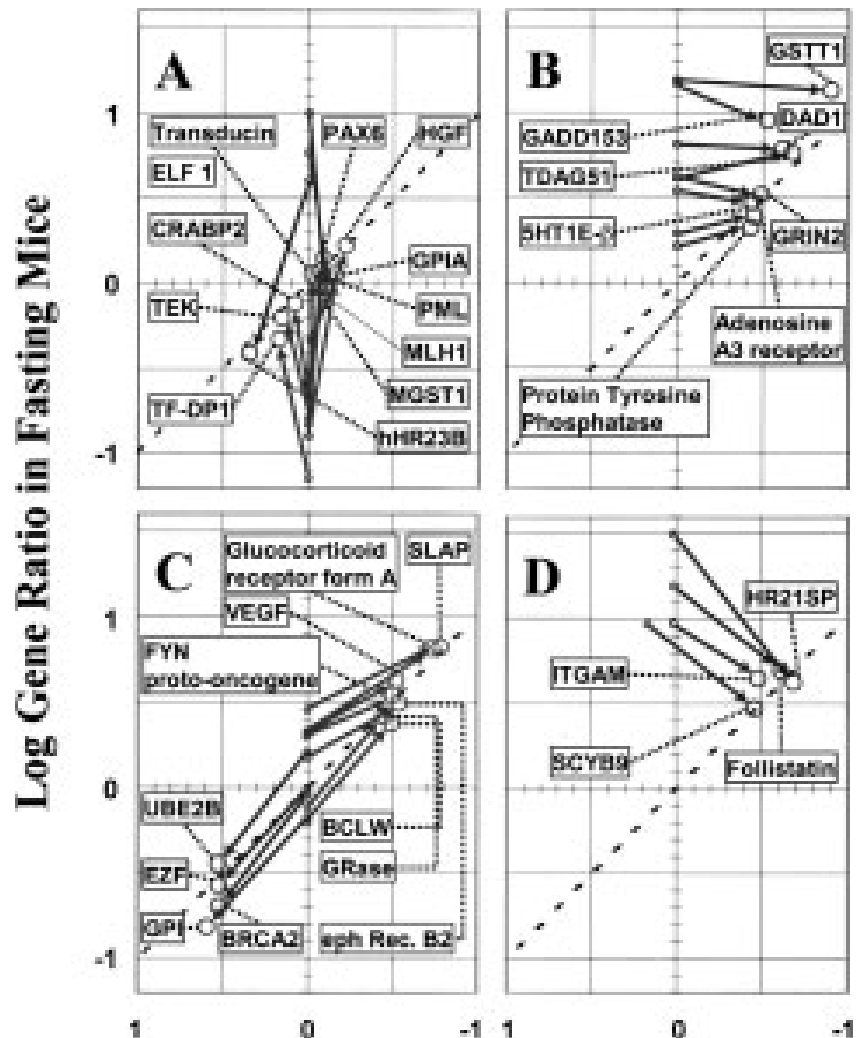

1
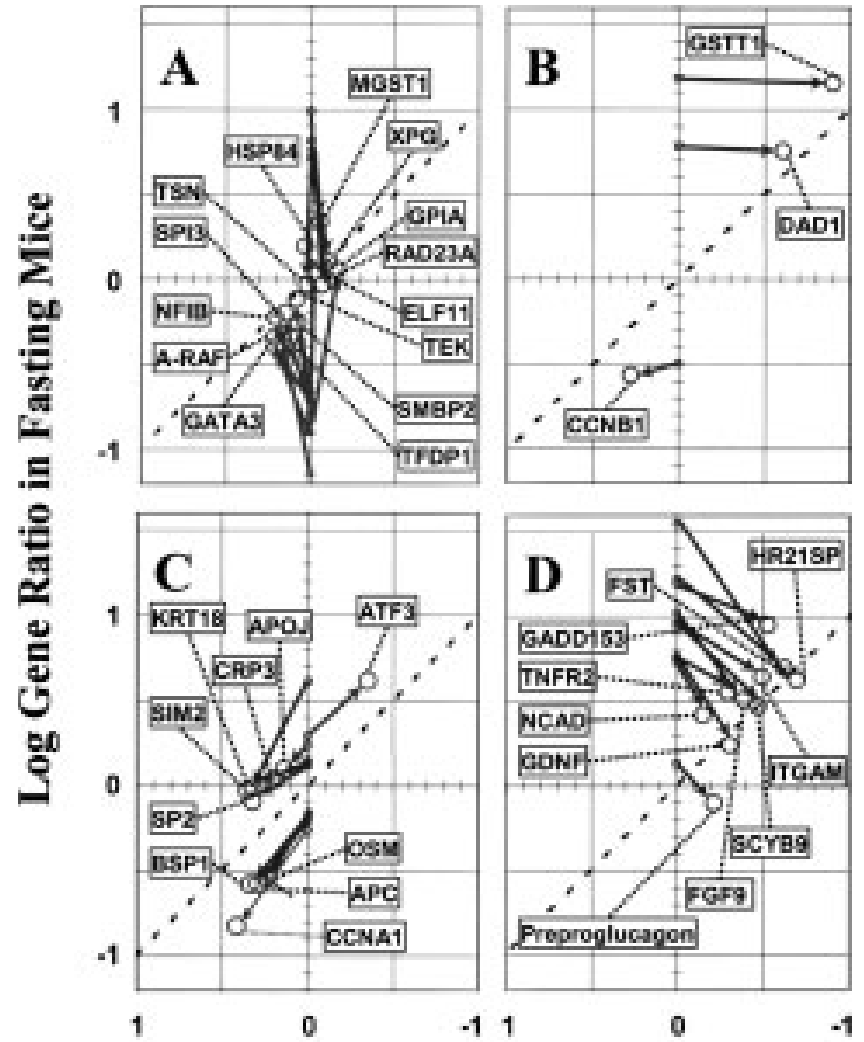

Log Gene Ratio in Fed Mice

Fig. 3. Classification of the effect of knocking out Anx7 on the response of gene expression to fasting stress sorted by mutation effect. The effects of the two experimental conditions, Anx7(+/-) and the stress of fasting are depicted in HELP diagrams for the top $5 \%$ of genes most affected by the mutation. The HELP diagrams are sorted according to the classes of the response to Anx7 knockout: The of genes (A) Anx7 knockout affects only gene expression in the fasting state (vertical vectors); (B) Anx7 knockout affects only gene expression in the fed state (horizontal vectors); (C) vectors parallel to the main diagonal; and (D) Anx7 knockout causes gene expression in both states to become equal (vectors pointing toward the main diagonal). Red vectors denote increased expression and blue vectors denote decreased expression in the fasting state.

mouse islet is arrayed in the graph as a large symbol. The genes in Figure 3A are particularly affected by the mutation, whose expression is either much greater or much less in the fasting state, but which are returned toward the origin by the mutation. The dashed line in the graph represents the diagonal, in which genes are equally expressed in the fed or fasted states. The HELP diagram thus enables one to appreciate, simply by inspection, which genes return toward the origin. This conclusion is consistent with the message from Figure 2 , but much more informative. The genes in Figure $4 \mathrm{~A}$ are equivalently analyzed, except that they come from the list of genes most affected by the knockout. In both cases the data cluster on the diagonal. Of the 14 genes in Figure 3A and the 15 genes in Figure 4A, 6 genes are present in common. The genes uniquely affected by the mutant, PAX6 and HGF, stand out by virtue of

Fig. 4. Classification of the effect of knocking out Anx7 on the response of gene expression to fasting stress sorted by stress effect. The effects of the two experimental conditions, Anx7(+/ ) and the stress of fasting are depicted in HELP diagrams for the top $5 \%$ of genes most affected by fasting. The HELP diagrams are sorted according to the classes of the response to Anx7 knockout: (A) Anx7 knockout affects only gene expression in the fasting state (vertical vectors); (B) Anx7 knockout affects only gene expression in the fed state (horizontal vectors); (C) vectors parallel to the main diagonal; and (D) Anx7 knockout causes gene expression in both states to become equal (vectors pointing toward the main diagonal). Red vectors denote increased expression and blue vectors denote decreased expression in the fasting state.

their historic association with islet development (see Discussion for specific references). The location on the diagonal means that the expression of these genes is the same in either fed or fasted states in the mutant, but not necessarily identical to expression in either fed or fasted states in the control.

The HELP diagram emphasizes angular clustering of genes affected by the mutation, and the angles can be analyzed in a systematic manner. The entries in Figure 3B are genes that all express significantly more in fasting than fed controls and are reduced in the mutant islet. The direction of the reduction is at an approximately $-45^{\circ}$ angle toward the diagonal, where all the genes cluster. Three of the four genes in Figure 3B are also found in Figure 4B. Of the genes in this set, preproglucagon and FGF9 from Figure 4D and 
Table 4. Quantitative RT-PCR of genes that are involved in islet biology

\begin{tabular}{lcc}
\hline \multicolumn{1}{c}{ Gene } & Islets & Liver \\
\hline GKRS 1 (glucokinase, related sequence 1) & $-1.06 \pm 0.17$ & $-2.53 \pm 0.31^{*}$ \\
PTEN (phosphatase and tensin homolog) & $-21.25 \pm 0.17^{*}$ & $3.94 \pm 0.092^{*}$ \\
GLUT2 (glucose transporter isoform 2) & $-5.06 \pm 0.21^{*}$ & $3.16 \pm 0.035^{*}$ \\
PDX 1 (pancreatic and duodenal homeobox) & $-4.56 \pm 0.14^{*}$ & 0.00 \\
IGF 1 (insulin-like growth factor 1) & $-2.57 \pm 0.13^{*}$ & $5.42 \pm 0.046^{*}$ \\
NEURO D 1 (neurogenic differentiation factor 1) & $-5.58 \pm 0.15^{*}$ & $1.91 \pm 0.18$ \\
NGN 3 (neurogenin 3) & $1.18 \pm 0.15$ & $-3.53 \pm 0.23^{*}$ \\
\hline
\end{tabular}

For qPCR results, data are means with SE for relative expression levels (arbitrary units). PCR conditions and the primer pairs used are as described in "Materials and Methods" section. Values are shown as a fold difference between mutant mice $(+/-)$ and their littermate control $(+/+)$, using the comparative $\mathrm{Ct}$ method (as described in method).

${ }^{*} p \leq 0.05, n=4,(-)=$ down regulated gene.

follistatin from Figure 3D stand out by virtue of their historic association with islet development. In Figure $3 \mathrm{C}$ and $4 \mathrm{C}$, we find genes that are significantly different from the average in the fasting states, but move approximately horizontally toward the diagonal. Thus a return to the diagonal is the common consequence of the mutation for these genes. This happens regardless of whether they are under- or overexpressed in the fasted state in control animals, or whether they are chosen from those most affected by either the mutation or fasting condition. In other words, the Anx7(+/-) mutation causes them to be equivalently expressed in both fed and fasted states. Finally, a variation on the theme of Figure $3 \mathrm{~B}$ and $4 \mathrm{~B}$ are found in Figures $3 \mathrm{C}$ and $4 \mathrm{C}$. These genes move in parallel with, and with few exceptions, generally toward the diagonal. For example, in Figure 4C, cytokeratin 18 (KRT18), a gene associated with ductal stem cell proliferation to form $\beta$ cells, is expressed significantly more in fasted than fed mutants $(+2.9$ SDs, Table 1$)$, but approximately equivalently in the control animals.

Validation and Analysis of Selected Gene Expression in Islets and Liver Tissue Using Real-time Quantitative RT-PCR

Candidate Anx7-regulated genes identified by our bioinformatic analysis and selected genes with historical importance for islet biology, not present in our arrays, were examined for their expression using quantitative real-time RT-PCR. As shown in Table 4, there is remarkable down-regulation of PTEN, Glut-2, and Neuro D 1 expression in isolated Anx7(+/-) islets but not in liver from the same animal. Thus, the effect of the mutation on islet gene expression is tissue specific. We note that PDX-1 and IGF-1 are down-regulated in mutant islets, in parallel to the results from the array study. We conclude that the differences noted by the gene arrays validly reflect authentic gene expression in islets.

\section{Discussion}

The principal conclusions from this study are that the acutely fasting state for the normal mouse results in significant and fundamental changes in expression of a limited number of genes in the islets of Langerhans. By contrast, in the case of the Anx7(+I-) knockout mouse, the genomic data clearly show that the mutation causes gene expression in mutant islets to be virtually independent of the recent nutritional history of the mutant mouse. Among islet genes affected by fasting in the control mouse are a set of genes classically associated with growth and development of the endocrine pancreas. In addition, there is a second set of genes, including certain transcription factors and DNA repair enzymes, which have not previously been so associated. With few exceptions, the expression levels of the genes associated with the fasting state in the normal mouse are very close to "fed" levels in the ANX7(+/-) mouse islets. The data therefore show that normal levels of Anx7 gene expression are required for control of nutritiondependent gene expression in mouse islets of Langerhans. A critical question deriving from these data is how the Anx7 gene can serve as a "gateway" for so many other genes involved in the nutritional response. Because the Anx7(+/-) mutation profoundly affects expression of the ITPR 3 gene, one possibility is that defective calcium signaling consequent to the Anx7(+/-) mutation may play an essential role in "gateway" function.

Loss of the Nutritional Genomic Response in the Anx7(+/-) Islet May Be Due to Defective $\mathrm{Ca}^{2+}$ Signaling in Mutant $\beta$ Cells

The basis of the experimental design for the study was the hypothesis that because ITPR3 expression 
was constitutively low in Anx7(+/-) $\beta$ cells, the ability of mutant islets to distinguish between the fed and fasted states might be lost. Fundamentally, the hypothesis is correct at the genomic level. But how could so many genes be gated by an Anx7 gene dosage effect? We have previously shown that the loss of ITPR3 gene expression prejudices both glucoseor acetylcholine-dependent release of $\mathrm{Ca}^{2+}$ from the endoplasmic reticulum in Anx7(+/-) mouse $\beta$ cells (20). This loss contributes to a profound reduction in the rate of the $\mathrm{Ca}^{2+}$-dependent insulin secretion from isolated mutant islets. The accompanying phenotype of islet hypertrophy and $\beta$ cell hyperplasia, reminiscent of the compensatory response that often accompanies type 2 diabetes, may also be $\delta$ compensatory in nature. The mechanism of this compensatory change could be due to the profound loss of PTEN (see Table 4). The PTEN $(+/-)$ and Anx7(+/-) mouse islets share similar structural characteristics of islet biology (23). In this sense, the PTEN and Anx7 heterozygotes are anatomic and functional phenocopies of each other. Presumably, the secretory defect expressed in individual $\beta$ cells is compensated by a massive increase in $\beta$ cell numbers. In the Anx7(+/-) mutant mouse there is also a subtle peripheral compensation in terms of modestly but significantly less insulin resistance and slightly more efficient glucose tolerance. However, the individual $\beta$ cells, which are most likely responsible for the majority of genomic responses documented, sense only their individually modest calcium signals. For that reason it is very likely that the cellular $\mathrm{Ca}^{2+}$ signaling defect contributes to the failure of the mutant $\beta$ cells to mount the appropriate global genomic response to the stress of a 16-hr fast. However, in a separately published study, we have further investigated the generality of this mutation on fasting stress by repeating this experimental paradigm on the adrenal gland of Anx7(+I-) knockout mice. We found that the genomic ability to respond to fasting stress was modified exactly like that shown here for islets, except that the relevant genes were those principally associated with development and historical function of the adrenal medulla (24). These data thus emphasize that a common Anx7-dependent signaling process affects the genomic response to fasting stress in a tissue-specific manner. Testing this hypothesis further is beyond the scope of this paper.

\section{The Fasting State Affects Islet Genes That Are Classically} Associated With the Development of the Endocrine Pancreas

The physiologic stress of a 16-hr fast had the remarkable consequence of affecting expression of a substantial number of genes that are associated in the literature database with islet development. We have therefore entertained the possibility that the acquired inability of the Anx7(+/-) mouse islets to discriminate between fed and fasted states might be the basis for the spectacular mutant islet phenotype of islet hypertrophy and $\beta$ cell hyperplasia (20). Classically, the pathway for development of the endocrine pancreas is initiated by ductal epithelial stem cells, marked by cytokeratin 18 (KRT18, mouse endoB, Figure 4C) (25-27). These stem cells differentiate into $\alpha$ cells, marked by preproglucagon (PPG, Fig. 4D), which then further differentiate into $\beta$ cells. Cytokeratin 18 is among the first of the intermediate filaments to be expressed during development, and is one of the major keratins expressed in epithelia of the type found in the pancreas, as well as liver and intestine $(28,29)$. Interestingly, autoantibodies against pancreatic cytokeratin have been described in type 1 diabetes (30). In control islets, the data show that both cytokeratin 18 (Fig. 4C) and PPG (Fig. 4D) are marginally affected by the fed versus fasting paradigm. However, in mutant islets, PPG gene expression is increased in the fed condition, whereas cytokeratin expression is somewhat increased in the fasting state. The fasting state is clearly a physiologic stressor for mice, and is presumably avoided if at all possible. Nonetheless, it is clear that the mutation affects the expression of both genes directly, corroborating the possibility of Anx7 gene dosage effects on fasting-induced $\beta$ cell differentiation from ductal stem cells.

A network of transcription factors have been identified that are required for development of all four endocrine cell lineages in islets from ductal stem cells (31). Of the many transcription factors implicated, our HELP diagram has identified mutational effects on PAX6, follistatin, and hepatocyte growth factor (HGF). PAX6 is one of several transcription factors known to be essential for islet development $(32,33)$. PAX6 binds to a common element in the promoters for glucagon, insulin, and somatostatin $(34,35)$, and is required for differentiation of $\alpha$ cells from ductal stem cells in mouse pancreas $(36,37)$. As shown in Figure $3 \mathrm{~A}$, fasting in the normal mouse also increases expression of the paired box gene PAX6. However, PAX6 is expressed equally in the mutant islet, and at levels equivalent to average expression of all genes in the mutant islet. The known developmental importance of PAX6 for islets of Langerhans leads us to consider this observation as of particular importance for the massive increase in $\beta$ cells occurring in the Anx7(+/-) mouse. Other PAX isoforms were not available in our array, and will be separately studied in the future.

Follistatin is a differentiation factor that binds to activin and is believed to control the formation of pancreatic endocrine cells $(38,39)$. As shown in Figure 3D, follistatin expression is vastly increased in the fasting control islets, but is expressed equivalently and substantially in both fed and fasted mutant islets. HGF is mitogenic for duct cells but not for $\beta$ cells in vitro (40), and has been reported to increase islet mass in vivo in transgenic mice (41). As shown in Figure $3 \mathrm{~A}$, fasting in the control mouse 
reduces the level of HGF expression in islets. However, in mutant mouse islets HGF expression is increased to a level above that of average gene expression in both fed and fasted animals. In summary, the effect of the Anx7(+/-) mutation on the expression of these transcription factors in islets seems to cause them to be constitutively increased, independently of the nutritional status of the mouse. It is therefore very likely that these genes may contribute to the hypertrophic islet phenotype typical of the Anx7(+/-) knockout mouse.

For the hypertrophic islets to exert their endocrine contributions, we anticipated that an increased vascular network of capillaries would have to be engineered into the islet structure. The HELP diagrams do illuminate possible contributions from vascular endothelial growth factor (VEGF), ephrin receptor B2, and TEK (the angiopoietin-1 receptor). For example, fasting in the normal mouse increases islet expression of vascular endothelial growth factor precursor (VEGF, Fig. 3C). However, as shown in Figure 3C, VEGF is expressed equally and at high levels in the fed and fasted states in the mutant islets. VEGF is important both for vascular development in the pancreas, as well as for $\beta$ cell maturation from pancreatic duct cells $(42,43)$. VEGF is synthesized in $\beta$ cells but not endothelial cells in human adult and fetal pancreas (44), and is a mitogen for pancreatic duct cells $(45,46)$. Vascular morphogenesis also requires contributions from ephrinB2 and its cognate receptor (47). Consistently, as shown in Figure 3C, the Eph receptor B2 is expressed at relatively low levels in the fasting control islet. Yet, just like VEGF, it is expressed in a vastly increased level in both fed and fasting Anx7(+/-) mutant islets. Finally, as shown in Figure $4 \mathrm{~A}$, TEK is poorly expressed in fasting control islets, but is substantially and equally expressed in both fed and fasted mutant islets. A combined and sustained coexpression of VEGF and angiopoietin-1 are known to provide a powerful stimulus to postnatal recruitment of vasculogenic stem cells (48). Angiopoietin-1 itself is also known to be a suppressor of apoptotic endothelial cell death (49). Although these observations are based on a relatively small proportion of the mouse genes potentially involved in vasculogenesis, the physiologic coherence of this set of mined-out genes argues that reduced Anx7 gene dosage, and the observed 50\% reduction in expressed Anx7 protein, drives an increase in vasculogenic signals to support the hypertrophic and hyperplastic states of islets in mutant animals.

While hypertrophic, the organization of $\beta$ - and non- $\beta$ cells in the mutant islet are essentially normal. There is a mostly peripheral distribution of $\alpha$ cells in the otherwise giant islets, and a central distribution of hyperplastic $\beta$ cells. $(20,21)$. Proper histologic structure in islets is known to be dependent on $N$-cadherin (NCAD) because, in the absence of NCAD, the distribution of $\alpha$ and $\beta$ cells in the islet becomes random (50). Furthermore, NCAD is substantially expressed in early glucagon-producing cells in the developing pancreas. Such cells occur early in the lineage leading to mature $\beta$ cells $(51,52)$. $\mathrm{N}$-CAM is also critical for the association of $\beta$ cell precursors to form islets during embryogenesis in mouse (53) and man (54). Consistently, we find that expression of NCAD precursor $(\mathrm{N}$-cadherin, Figure 4D) is profoundly activated in expression in fasting normal mouse islets. By contrast, NCAD expression returns toward equivalent but average expression levels in both fed and fasting mutants. Once again, the Anx7(+/-) islet cells fail to discriminate between fed and fasted states for expression of yet another developmentally important gene.

\section{Identification of Genes Associated With the Anx7(+/-) Mutation That Are Not Traditionally Associated With Islet of Langerhans Biology}

A remarkable cluster of significantly and uniquely changing genes, specifically associated with fasting stress, may yield the most relevant mechanistic insights underpinning the giant islet phenotype in the Anx7(+/-) mice. These may also be important because, as noted, they have not previously been associated with islet biology. As shown in Figures 3 and 4 , we find that many of these uniquely changing genes are associated either with repair of damaged DNA or with gene transcription. For example, the UV excision repair protein RAD23 homolog B (55) (hHR23B, Figure 3A) is highly expressed in fasting control islets relative to the fed state. However, hHR23B is substantially changed to equivalent and lower expression in the mutant islets. By contrast, expression of the UV excision repair protein homolog A (56) (RAD23A, Figure 4A) is strongly suppressed in fasting mutants, but changes to equivalent but average expression in islets of both fed and fasted mutant mice. Like RAD23A, the DNA mismatch repair protein MutL homolog (MLH1, Figure 3A) is also reduced in fasting control islets, but changes to equivalent but average expression in islets of both fed and fasted mutant mice. Xeroderma pigmentosum group G complementing protein (XPG, Figure 4A), a gene coding for an enzyme known to be active in repair of x-ray damage to DNA, is elevated in expression in fasting control islets, but is reduced to equivalent expression in both fed and fasting mutant islets. The MLHI DNA mismatch repair gene (HR2 1sp, Fig. 3D) is a calcium-binding protein involved in ionizing radiation-induced DNA doublestrand break repair $(57,58)$. To the best of our knowledge, these mismatch repair enzymes have not been shown previously to have a specific phenotypic relationship to the pancreas or to islets of Langerhans in particular. The stress of the fasting state thus appears to induce a heightened capacity for DNA repair, which becomes all but constitutive in the Anx7(+/-) mouse islet.

The fed versus fasting paradigm also affects a number of unique genes in islets, which are known 
to be associated either with transcription directly or with signaling pathways leading to enhanced transcription. In all cases they are enhanced in expression under fasting conditions only in mutant islets. One is the CCAAT/enhancer binding protein delta (C/EBP delta; CRP3, Fig. 4C). C/EBP plays many roles in the body. However, C/EBP is known to be regulated during murine postnatal colon development, and therefore has a literature-based developmental relationship with the GI tract (59). The CCAAT/enhancer binding proteins are also associated with differential insulin gene expression (60), and with experimental diabetes (61). Another of these unique transcription factors is the src-like adapter protein (SLAP, Fig. 3C), which is activated in fasting control islets, but is expressed in equivalent but elevated levels in fed or fasted mutant islets. Finally, there is the U2 small nuclear ribonucleoprotein auxiliary factor subunit (SP2, Fig. 4C). SP2 is an imprinted gene which binds to G-rich promoter domains $(62,63)$. As pointed out for the DNA repair genes, these latter genes, except for C/EBP, are also typified by a lack of a literature-based relationship to the pancreas or to islet cell biology. For that reason these novel genes alert us to the existence of hitherto unknown pathways to the development of islets, which could be of potential use for both diagnostics and therapeutics.

Finally, there are a set of tumor suppressor genes and proto-oncogenes whose expression is modified by nutritional stress. Inasmuch as the ANX7 gene functions as a tumor suppressor gene for human prostate cancer (64), the actions of fasting and the Anx7(+/-) mutation on other tumor suppressor genes may be important. The adenomatous polyposis coli protein (APC, Fig. 4C) and the breast cancer type 2 susceptibility protein (BRCA2, Fig. 3C) are both expressed at low levels in the fasting control islet. However, they are expressed equivalently and lower in both fed and fasted mutant mouse islets. It is possible that reductions in activity of these types of genes may enhance growth and proliferation, and thus contribute to islet hypertrophy in the Anx7(+/-) mouse. Conversely, the fyn proto-oncogene (FYN, Fig. 3C) is enhanced in the fasting control islet, and is equally highly expressed in fed or fasted mutant islets.

\section{Conclusion}

We suspect that this information may prove useful in devising pharmacogenomic targets for drugs or genes whose purpose might be to either grow new islets for type 1 diabetes or to reactivate otherwise poorly responsive islets for type 2 diabetes. This type of experiment, contrasting the global expression of genes in the fed and fasted states, has to our knowledge not previously been performed. It is therefore the first example of what we suggest could be usefully termed nutritional genomics. In principle, nutritional genomics should be able to yield novel information regarding the often subtle influence of nutrients, toxins, mutations, and disease on the fundamental biology of islets or other tissues. Among this class of such genetic components we now include Anx7, whose requirement for physiologic nutritional control of gene expression in islets is profound.

\section{References}

1. Malaisse WJ. (1983) Insulin release: the fuel concept. Diabetes Metab. 4: 313-320.

2. O'Rahilly SO, Hosker JP, Rudenski AS, et al. (1988) The glucose stimulus-response curve of the beta-cell in physically trained humans, assessed by hyperglycemic clamps. Metabolism 10: 919-923.

3. Lang DA, Matthews DR, Peto J, Turner RC. (1979) Cyclic oscillations of basal plasma glucose and insulin concentrations in human beings. N. Engl. J. Med. 301: 1023-1027.

4. Pratley RE, Weyer C. (2001) Insulin resistance and insulin secretory dysfunction are independent predictors of worsening of glucose tolerance during each stage of type 2 diabetes development. Diabetic Care 1: 89-94.

5. Mears D, Atwater I. (2002) Electrophysiology of the pancreatic $\beta$-cell. In Leroith D, Taylor SI, Olefsky JM (eds). Philadelphia, PA (Lippincott Williams \& Wilkins) Diabetes Mellitus. pp 47-61.

6. Ashcroft FM, Proks P, Smith PA, et al. (1994) Stimulus-secretion coupling in pancreatic beta cells. J. Cell Biochem. 55: 54-65.

7. Prentki M, Glennon MC, Geschwind JF, et al. (1987) Cyclic AMP raises cytosolic $\mathrm{Ca}^{2+}$ and promotes $\mathrm{Ca}^{2+}$ influx in a clonal pancreatic beta-cell line (HIT T-15). FEBS Lett. 220: 103-107.

8. Laybutt DR, Kaneto H, Hasnkamp W, et al. (2002) Increased expression of antioxidant and antiapoptotic genes in islets that may contribute to beta-cell survival during chronic hyperglycemia. Diabetes. 51: 413-423.

9. Herrera PL. (2002) Defining the cell lineages of the islets of Langerhans using transgenic mice. Int. J. Dev. Biol. 46: 97-103.

10. Hirschi KD, Kreps JA, Hirschi KK. (2001) Molecular approaches to studying nutrient metabolism and function: an array of possibilities. J. Nutr. 131: 1605S-1609S.

11. Cao SX, Dhahbi JM, Mote PL, Spindler SR. (2001) Genomic profiling of short- and long-term caloric restriction effects in the liver of aging mice. Proc. Natl. Acad. Sci. U.S.A. 98: 1063010635.

12. Kita Y, Shiozawa M, Weihoong J, et al. (2002) Implications of circadian gene expression in kidney, liver and the effects of fasting on pharmacogenomic studies. Pharmacogenetics 12: 55-65.

13. Srivastava M, Eidelman O, Pollard HB. (1999) Pharmacogenomics of the cystic fibrosis transmembrane conductance regulator (CFTR), and of the cystic fibrosis drug CPX using genome microarray analysis. Mol. Med. 5: 753-767.

14. Eidelman O, Srivastava M, Zhang J, et al. (2001) Genes from the TNFaR/NFkB pathway control the pro-inflammatory state in cystic fibrosis epithelial cells. Mol. Med. 7: 523-534.

15. Gilon P, Shepherd RM, Henquin JC. (1993) Oscillations of secretion driven by oscillations of cytoplasmic $\mathrm{Ca}^{2+}$ as evidences in single pancreatic islets. J. Biol. Chem. 268: 2226522268.

16. Lawrence MC, Bhatt HS, Watterson JM, Easom RA. (2001) Regulation of insulin gene transcription by a $\mathrm{Ca}\left({ }^{2+}\right)$-responsive pathway involving calcineurin and nuclear factor of activated T cells. Mol. Endocrinol. 10: 1758-1767.

17. Lee B, Gai W, Laychock SG. (2001) Proteosomal activation mediates down-regulation of inositiol trisphosphate receptor and calcium mobilization in rat pancreatic islets. Endocrinology 142: 1744-1751.

18. Lee B, Jonas JC, Weir GC, Laychock SG. (1999) Glucose regulates expression of inositol 1,4,5,-trisphosphate receptor 
isoforms in isolated rat pancreatic islets. Endocrinology 140: 2173-2182.

19. Lee B, Laychock SG. (2000) Regulation of inositiol trisphosphate receptor isoform expression in glucose-desensitized rat pancreatic islets: role of cyclic adenosine 3', 5'-monophosphate and calcium. Endocrinology 141: 1394-1402.

20. Srivastava M, Atwater I, Glasman M, et al. (1999) Defects in IP3 receptors expression, $\mathrm{Ca}^{2+}$-signaling and insulin secretion in the anx7 (+/-) knockout mouse. Proc. Natl. Acad. Sci. U.S.A. 96: $13783-13788$.

21. Goping G, Leapman R, Pollard HB, Srivastava M. (2002) Mapping protein expression in mouse pancreatic islets by immunolabeling and electron spectroscopic imaging. Microscopy Research and Techniques (In Press)

22. Boschero AC, Malaisse WJ. (1979) Stimulus-secretion coupling of glucose-induced insulin release. XXIX. Regulation of $86 \mathrm{Rb}+$ efflux from perfused islets. Am. J. Physiol. 236: E139-E146.

23. Butler M, McKay RA, Popoff IJ, et al. (2002) Specific inhibition of PTEN expression reverses hyperglycemia in diabetic mice. Diabetes 51: 1028-1034

24. Srivastava M, Kumar P, Leighton $X$, et al. (2002) Influence of the Anx7 (+/-) knockout mutation and fasting stress on the genomics of the mouse adrenal gland. Ann. N. Y. Acad. Sci. 971: 53-70.

25. Bonner-Weir S, Baxter LA, Schuppin GT, Smith FE. (1993) A second pathway for regeneration of adult exocrine and endocrine pancreas. A possible recapitulation of embryonic development. Diabetes 42: 1715-1720.

26. Boj S, Parrizas M, Maestro MA, Ferrer J. (2001) A transcription factor regulatory circuit in differentiated pancreatic cells. Proc. Natl. Acad. Sci. U.S.A. 98: 14481-14486.

27. Bouwens L, Wang RN, De Blay E, et al. (1994) Cytokeratins as markers of ductal cell differentiation and islet neogenesis in the neonatal rat pancreas. Diabetes 43: 1279-1283.

28. Steinert PM, Roop DR. (1988) Molecular and cellular biology of intermediate filaments. Annu. Rev. Biochem. 57: 593-625.

29. Kulesh DA, Oshima RG. (1988) Cloning of the human keratin 18 gene and its expression in nonepithelial mouse cells. Mol. Cell Biol. 8: 1540-1550.

30. Kobayashi T, Nakanishi K, Kajio H, et al. (1990) Pancreatic cytokeratin: an antigen of pancreatic exocrine cell autoantibodies in type 1 (insulin-dependent) diabetes mellitus. Diabetologia 33: 363-370.

31. Gradwohl G, Dierich A, LeMeur M, Guillemot F. (2000) Neurogenin 3 is required for the development of the four endocrine cell lineages of the pancreas. Proc. Natl. Acad. Sci. U.S.A. 97: 1607-1611.

32. Yamaoka T, Itakura M. (1999) Development of pancreatic islets. Int. J. Mol. Med. 3: 247-261.

33. Beimar F, Argenton F, Schmidtke R, et al. (2001) Pancreas development in the zebrafish: early dispersed appearance of endocrine hormone expressing cells and their convergence to form the definitive islet. Dev. Biol. 230: 189-203.

34. Sander M, Neubuser A, Kalamaras J, et al. (1997) Genetic analysis reveals that PAX6 is required for normal transcription of pancreatic hormone genes and islet development. Genes Devel. 11: 1662-1673.

35. Hill ME, Asa SL, Drucker DJ. (1999) Essential requirement for Pax6 in control of enteroendocrine proglucagon gene transcription. Mol. Endocrinol. 13: 1474-1486.

36. St. Onge L, Sosa-Pineda B, Chowdhury K, et al. (1997) Pax6 is required for differentiation of glucagon-producing alpha cells in mouse pancreas. Nature 387: 406-409.

37. Yamaoka T, Yano M, Yamada T, et al. (2000) Diabetes and pancreatic tumours in transgenic mice expressing Pax6. Diabetologia 43: 332-339.

38. Shibata H, Kanzaki M, Takeuchi T, et al. (1996) Two distinct signaling pathways activated by activin A in glucose-responsive pancreatic beta-cell lines. J. Mol. Endocrinol. 16: 249-258.

39. Kojima I. (1997) Effect of activin A on the formation of pancreatic endocrine cells. In Aono T, Sugino H, Vale W (eds). Inhibin, Activin and Follistatin. Springer-Verlag, Berlin, Heidelberg, Vienna, and Milan; pp. 189-203.
40. Lefebvre VH, Otonkoski T, Ustinov J, et al. (1998) Culture of adult human islet preparations with hepatocyte growth factor and $804 \mathrm{G}$ matrix is mitogenic for duct cells but not for betacells. Diabetes 47: 134-137.

41. Garcia-Oceana A, Takane KK, Syed MA, et al. (2000) Hepatocyte growth factor overexpression in the islet of transgenic mice increases beta cell proliferation, enhances islet mass, and induces mild hypoglycemia. J. Biol. Chem. 275: 12261232.

42. Christofori G, Naik P, Hanahan D. (1995) Vascular endothelial growth factor and its receptors Flt-1 and flk-1 are expressed in normal pancreatic islets and throughout islet call tumorigenesis. Mol. Endocrinol. 9: 1760-1770.

43. Gorden DL, Mandriota SJ, Montesano R, et al. (1997) Vascular endothelial growth factor is increased in devascularized rat islets of Langerhans in vitro. Transplantation 63: 436-443.

44. Kuroda M, Oka T, Oka Y, et al. (1995) Colocalization of vascular endothelial growth factor (vascular permeability factor) and insulin in pancreatic islet cells. J. Clin. Endocrinol. Metab. 80: $3196-3200$.

45. Oberg-Welsh C, Sandler S, Andersson A, Welsh M. (1997) Effects of vascular endothelial growth factor on pancreatic duct cell replication and the insulin production of fetal islet-like cell clusters in vitro. Mol. Cell Endocrinol. 126: 125-132.

46. Rooman I, Schuit F, Bouwens L. (1997) Effect of vascular endothelial growth factor on growth and differentiation of pancreatic ductal epithelium. Lab. Invest. 76: 225-232.

47. Adams RH, Diella F, Hennig S, et al. (2001) The cytoplasmic domain of the ligand ephrin B2 is required for vascular morphogenesis but not cranial neural crest migration. Cell 104: 57-69.

48. Hattori K, Dias S, Heissig B, et al. (2001) Vascular endothelial growth factor and angiopoietin-1 stimulate postnatal hematopoiesis by recruitment of vasculogenic and hematopoietic stem cells. J. Exp. Med. 193: 1005-1014.

49. Papapetropoulos A, Fulton D, Mahboubi K, et al. (2000) Angiopoietin-1 inhibits endothelial cell apoptosis via the Akt/survivin pathway. J. Biol. Chem. 275: 9102-9105.

50. Esni F, Taljedal IB, Perl AK, et al. (1999) Neural cell adhesion molecule (N-CAM) is required for cell type segregation and normal ultrastructure in pancreatic islets. J. Cell Biol. 144: 325-337.

51. Moller CJ, Christgau S, Williamson MR, et al. (1992) Differential expression of neural cell adhesion molecule and cadherins in pancreatic islets, glucagonomas and insulinomas. Mol. Endocrinol. 6: 1332-1342.

52. Larue L, Antos C, Butz S, et al. (1996) A role for cadherins in tissue formation. Development 122: 3185-3194.

53. Dahl U, Sjodin A, Semb H. (1996) Cadherins regulate aggregation of pancreatic beta cells in vivo. Development 122: 2895-2902.

54. Gaidar YA, Lepekhin EA, Sheichetova GA, Witt M. (1998) Distribution of N-cadherin and NCAM in neurons and endocrine cells of the human embryonic and fetal gastroenteropancreatic system. Acta Histochem. 100: 83-97.

55. Ortolan TG, Tongaonkar P, Lambertson D, et al. (2000) The DNA repair protein rad23 is a negative regulator of multiubiquitin chain assembly. Nat. Cell Biol. 2: 601-608.

56. McKay MJ, Troelstra C, van der Spek P, et al. (1996) Sequence conservation of the rad 21 Schizosacchararomyces pombe DNA double strand break repair gene in human and mouse. Genomics 36: 305-315.

57. Huang RP, Adamson ED. (1995) A role for Egr-1 in cell survival following ultraviolet irradiation. Oncogene 10: 467-475.

58. Lim CP, Jain N, Cao X. (1998) Stress-induced immediate early gene egr-l involves activation of $\mathrm{p} 38 / \mathrm{JNK} 1$. Oncogene 16: $2915-2926$.

59. Blais S, Boudreau F, Beaulieu JF, Asselin C. (1995) CCAAT/enhancer binding protein isoforms expression in colon of neonatal mice. Dev. Dyn. 204: 66-76.

60. Seufert J, Weir GC, Habener JF. (1998) Differential expression of the insulin gene transcriptional repressor CCAAT/ enhancer-binding protein beta and transactivator islet/ 
duodenum homeobox-1 in rat pancreatic beta cells during the development of diabetes mellitus. J. Clin. Inv. 101: 2528-2539.

61. Zador IZ, Hsieh CC, Papaconstantinou J. (1998) Renal CCAAT/enhancer bonding proteins in experimental diabetes mellitus. Nephron 79: 312-316.

62. Hatada I, Nabetani A, Arai Y, et al. (1997) Aberrant methylation of an imprinted gene U2afl-rs1 (SP2) caused by its own transgene. J. Biol. Chem. 272: 9120-9122.
63. O'Bryan JP, Songyang Z, Cantley L, et al. (1996) A mammalian adapter protein with conserved src homology 2 and phosphotyrosine binding domains is related to Shc, and is specifically expressed in the brain. Proc. Natl. Acad. Sci. U.S.A. 93: 2729-2734.

64. Srivastava M, Bubendorf L, Nolan L, et al. (2001) ANX7, a candidate tumor-suppressor gene for prostate cancer. Proc. Natl. Acad. Sci. U.S.A. 98: 4575-4580. 